\title{
Recent Advances Toward the Use of Mesoporous Silica Nanoparticles for the Treatment of Bacterial Infections
}

Rafael R Castillo'

María Vallet-Regí ${ }^{1-3}$

'Dpto. Química en Ciencias Farmacéuticas, Facultad de Farmacia, Universidad Complutense de Madrid, Madrid, 28040, Spain; ${ }^{2}$ Centro de Investigación Biomédica en Red-CIBER, Madrid, 28029, Spain; ${ }^{3}$ Instituto de Investigación Sanitaria Hospital 12 de Octubre-imas I2, Madrid, 2804I, Spain

Correspondence: Rafael R Castillo; María Vallet-Regí

Dpto. Química en Ciencias Farmacéuticas,

Facultad de Farmacia, Universidad

Complutense de Madrid, Plaza Ramón y

Cajal s/n, Madrid, 28040, Spain

Tel +349l 394 I843

Email rafcas0I@ucm.es; vallet@ucm.es

\begin{abstract}
It is a fact that the use of antibiotics is inducing a growing resistance on bacteria. This situation is not only the consequence of a drugs' misuse, but a direct consequence of a widespread and continuous use. Current studies suggest that this effect could be reversed by using abandoned antibiotics to which bacteria have lost their resistance, but this is only a temporary solution that in near future would lead to new resistance problems. Fortunately, current nanotechnology offers a new life for old and new antibiotics, which could have significantly different pharmacokinetics when properly delivered; enabling new routes able to bypass acquired resistances. In this contribution, we will focus on the use of porous silica nanoparticles as functional carriers for the delivery of antibiotics and biocides in combination with additional features like membrane sensitizing and heavy metal-driven metabolicdisrupting therapies as two of the most interesting combination therapies.
\end{abstract}

Keywords: mesoporous silica, bacteria, infection, combination therapy, drug delivery

\section{Introduction}

The discovery of penicillin enabled modern societies to cope with a large number of diseases caused by bacteria; diseases that until then, lacked an effective treatment and caused a large number of victims. Since that moment and upon democratization of antibiotics, infections could be controlled. However, this effect pushes bacteria to evolve and be more and more resistant against antibiotics, pushing too the researchers to find and develop more sophisticated compounds able to keep infections at bay. ${ }^{1,2}$ Nevertheless and unfortunately, the current situation suggests that acquired resistance grows faster than the development of new-generation antibiotics. ${ }^{3,4}$ However, the arrival of nanotechnology has permitted us to design new strategies to deliver these old antibiotics to bacteria in a different manner, ${ }^{5-7}$ just like that which happened in other branches of nanomedicine, such as cancer.

Among all the available nanotechnologies suitable to treat infections, ${ }^{6,8,9}$ we will focus herein on the use of porous silica-based technologies. They are one of the few materials that can easily combine in single entities an efficient drug-delivery profile, ${ }^{10-14}$ as reported by our group two decades ago, ${ }^{15,16}$ together with a facile (bio)chemical modification. These two complementary aspects permit us to create fancy multicomponent nanodevices able to exert combination therapy ${ }^{17,18}$ onto cells; as already covered by us in several bibliographic revisions on cancer ${ }^{17-19}$ and infection..$^{7,8,12}$ In addition to this synthetic modularity it is also important to 
remark on the advances made on increasing batchreproducibility and scale-up, which will allow us to overcome laboratory-scale bottlenecks and address semi-industrial synthesis $^{20}$ and thus face the commercialization of antibiotic nanodevices.

Regarding the chemical species to be delivered by mesoporous silica carriers it is possible to find typical antibiotics, but also peptides and proteins ${ }^{21}$ or plant extracts; although most of the examples deal with the delivery of small-sized molecules. At this point, we will address a comprehensive study of the different strategies followed to incorporate such antibiotics into silica nanocarriers; although again, most of reported strategies deal with the use of typical antibiotics. Apart from this systematic study on the combination of antibiotics and mesoporous silica nanoparticles (MSNs), we will also address the combination of MSNS with other biocidal species such as metals and poly-ionic species that show promising antibacterial effects and could be easily combined with the in-pore loading and delivery of drugs.

The intrinsic advantages of MSNs over other types of nanomaterials go beyond their porous structure capable of loading drugs of a different nature. For instance, among inorganic particles MSN have a superior loading capacity over solid nanoparticles such as iron oxide, gold and silver nanostructures and carbon-based systems such as nanotubes and graphene. ${ }^{22}$ Regarding biocompatibility, MSNs have a superior performance over nondegradable gold and carbon-based structures. ${ }^{23}$ This is a direct consequence of a water-driven dissolution ${ }^{24}$ that permits an effective clearance from tissues. This effect, extensively reviewed by us and other research groups during the last years, ${ }^{25-27}$ is not as quick as the clearance showed by iron oxides, but enough to prevent chronic toxicities. When compared with organic nanosystems such as liposomes, polymeric nanoparticles and dendrimers, MSNs have a superior structural and chemical stability and ease of functionalization, which permits them to develop synthetic modifications upon loading. But one of the most important features of silica is its enormous versatility of prepared hybrid systems which would be hardly prepared with other materials. Among its inconveniences, it should be remarked the stiffness of the resulting particles that unless properly prepared may lead to undesired accumulations in alveoli and blood capillaries that may produce embolisms. Regarding antibiotic effects, the topic of the current review, silica has no relevant effects on the bacteria, being silver colloids with a superior antibiotic efficacy either as therapeutics or adjuvants. ${ }^{28}$ In summary, we have chosen to review MSNs on antibacterial nanosystems because their drug delivery properties, stability, and combination versatility will provide them a brilliant future in the development of new generation antibiotics.

\section{Delivery of Antibiotic Compounds Drug Delivery Employing Surface-modified Silica Particles}

The modification of particles with antibiotics was one of the first nanotechnological strategies to face bacterial infection, as it could be implemented in most nanoparticles

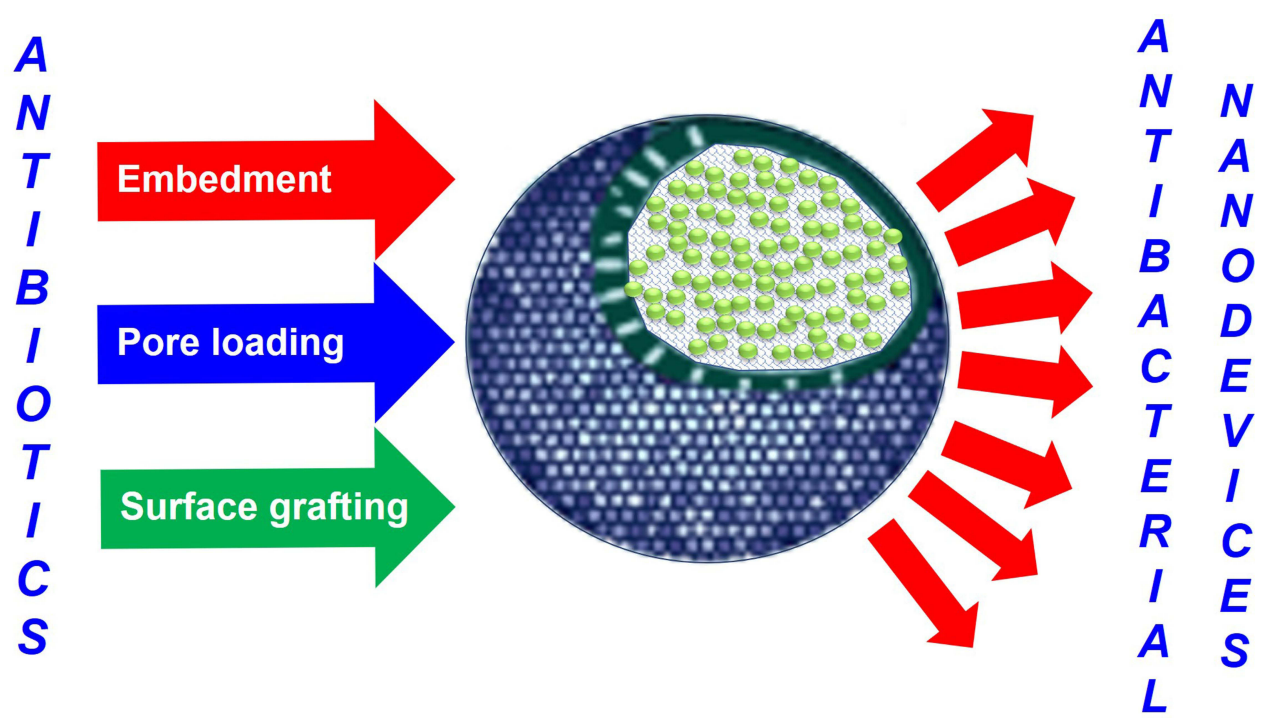

Figure I Strategies to prepare antibiotic-loaded nanoparticles. The possibility of drug release feature would be enabled or not depending on the methodology employed. 
with ease (Figure 1). Along this line, and focusing on silica-based nanosystems, Qi et al pioneered the use of these nanoparticle-antibiotic conjugates to treat infections. In their work the authors coupled the vancomycin glycopeptide onto MSNs to obtain a highly biocompatible hybrid nanodevice. This system was able to achieve selective recognition and antibiotic effect over pathogenic gram-positive bacteria infecting macrophage-like cells. ${ }^{29}$ In this case, the recognition between the MSNs $\subset$ Van and the gram-positive bacterial walls occurred due to a highly specific interaction between the glycopeptide and the terminal D-Ala-D-Ala moieties present on walls. In contrast, the interaction of MSNs $\subset$ Van with gram-negative bacteria was attributed to nonspecific electrostatic interactions between MSNs $\subset$ Van and the negatively charged bacterial walls. As a result, the nanosystem achieved a minimum inhibitory concentration (MIC) for Staphylococcus aureus around $200 \mu \mathrm{g} / \mathrm{mL}$, while viabilities on eukaryotic cells were above $90 \%$ with up to $1 \mathrm{mg} / \mathrm{mL}$ concentrations. In vivo assays on mice proved a drop in bacterial colonyforming units (CFUs) 10-fold, which permitted us to augment survival of infected mice. In a similar approach by Agnihotriet al, there were reported the use of aminoglycoside-conjugated MSNs to treat resistant bacteria. ${ }^{30}$ On their example a convenient epoxide modification onto the MSNs' surfaces permitted us to graft antibiotic aminoglycosides (gentamicin, neomycin, and kanamycin) throughout their amino functions. The resulting systems had a nice colloidal stability due to the positively charged outermost layer but without significant hemolysis rates, which may permit their intravenous administration. Indeed, in all tested bacteria the hybrid had a significant bacteriostatic effect, maintaining OD below 0.2, which indicates the absence of forming biofilms. (Table 1)

Another interesting possibility to develop antibacterial nanoparticles was tackled by Dong et al who explored the possibilities of $N$-halamine compounds (former hypochlorite releasers) as antibacterial agents. On their first contribution, the authors prepared a copolymer of MMA and allyl-barbituric acid onto $\mathrm{SiO}_{2}$ NPs which were then oxidized with $\mathrm{NaClO}$ to provide the corresponding halamine. ${ }^{31}$ In a more recent example the allyl-barbituric acid was replaced by a tetramethylpiperidine (TMP) that upon oxidation with $\mathrm{NaClO}$ provided the desired $N$-halamine-loaded particles. ${ }^{32}$ As a result both systems were able to promote bacterial death on gram-positive and gram-negative bacteria ( $P$. aeruginosa, $S$. aureus, and Escherichiacoli) due to a sustained chlorine release.
In a comparison between both models, the best antibacterial effect corresponds to the TMP-containing copolymer, which permitted us to obtain thicker coatings and hence higher chlorine deliveries. Nevertheless, the toxic effect of intracellular delivery of highly reactive chlorine species, may limit the application of these kind of nanodevices into living systems, as they would probably destroy eukaryotic cells and bacteria alike. Nevertheless, it is a promising strategy for the destruction of bacteria in nonliving systems. (Table 1)

\section{Pore Loading and Delivery of Antibiotic Drugs}

Another valuable strategy for antibiotic delivery in employing their three-dimensional structure to host and release drugs. This approach was first reported by Capeletti et al, who prepared tetracycline-loaded $\mathrm{SiO}_{2}$ NPs in situ from TEOS and a solution of tetracycline and ammonia. ${ }^{33}$ The in vitro evaluation showed that encapsulation improved the killing effect on E. coli, although as well as nonloaded $\mathrm{SiO}_{2} \mathrm{NPs}$, which suggests a particle-assisted antibacterial effect. However, as the system was not tested on eukaryotic cells, it may be possible that this strategy of surface unmodified particles may not be suitable for in vivo application.

Apart from typical delivery, several groups have also focused their research on how the morphology, textural properties and functionalization affect the drug load and delivery processes and how this affects the overall antibacterial effect. In an example by Nor et al the authors studied the effect of different roughness of silica nanoparticles in the release of vancomycin. ${ }^{34}$ In this work different sets of nanoparticles were prepared with different porosities and roughnesses, which provided significant differences between them on their hydrophobic properties. The systems employed were smooth hollow MSNs (H-MSNs), rough solid $\mathrm{SiO}_{2} \mathrm{NPs}$ ( $\mathrm{R}-\mathrm{SiO}_{2} \mathrm{NPs}$ ), and rough hollow MSNs (RH-MSNs). The authors discovered that RHMSNs performed better because these particles showed higher loading capacities as a consequence of the internal void, together with a more sustained release due to the more hydrophobic surface roughness. However, the associated antibacterial effect of vancomycin-loaded H-MSNs and RH-MSNs did not differ significantly against $E$. coli formed colonies, as the OD (600 nm) obtained showed similar values. However, the time-dependent antibacterial study proved that RH-MSNs were able to fully destroy 


\begin{tabular}{|c|c|c|c|c|c|c|c|c|c|c|c|}
\hline$\stackrel{\ddot{\Phi}}{\ddot{\alpha}}$ & & ని & ㅇ & $\bar{m}$ & $\tilde{m}$ & $\tilde{m}$ & $\stackrel{+}{m}$ & $\stackrel{\mathscr{n}}{m}$ & $\stackrel{m}{m}$ & $\hat{m}$ & $\stackrel{\infty}{m}$ \\
\hline 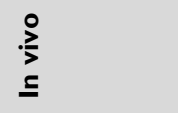 & & $\begin{array}{l}\stackrel{0}{0} \\
\stackrel{0}{0} \\
\Sigma\end{array}$ & $\begin{array}{l}\stackrel{0}{0} \\
\text { zo }\end{array}$ & $\begin{array}{l}\text { õ } \\
\text { ż }\end{array}$ & $\begin{array}{l}0 \\
\text { zo }\end{array}$ & $\stackrel{0}{0}$ & $\begin{array}{l}0 \\
\text { zo } \\
z\end{array}$ & $\begin{array}{l}\stackrel{0}{0} \\
\text { zo }\end{array}$ & $\stackrel{0}{0}$ & 气ั & $\stackrel{0}{\stackrel{0}{0}}$ \\
\hline 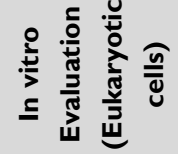 & & 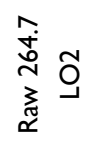 & $\begin{array}{l}0 \\
\stackrel{0}{0} \\
z\end{array}$ & $\stackrel{0}{\check{0}}$ & :0 & $\begin{array}{l}\stackrel{-}{o} \\
\stackrel{N}{~} \\
\stackrel{\text { m}}{I}\end{array}$ & $\begin{array}{l}0 \\
\stackrel{0}{0} \\
z\end{array}$ & $\stackrel{0}{0}$ & 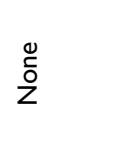 & $\begin{array}{l}0 \\
\stackrel{0}{0}\end{array}$ & $\stackrel{0}{\tilde{O}}$ \\
\hline 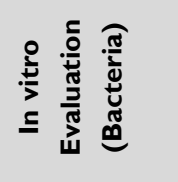 & & 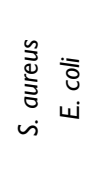 & 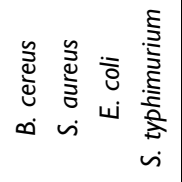 & 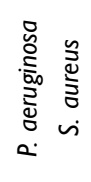 & 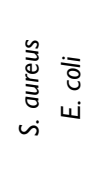 & $\begin{array}{l}\overline{8} \\
\dot{w}\end{array}$ & $\begin{array}{l}\overline{8} \\
\dot{u}\end{array}$ & 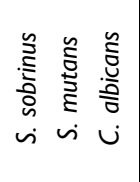 & : & 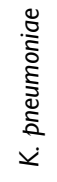 & $\begin{array}{l}\overline{8} \\
\dot{w}\end{array}$ \\
\hline 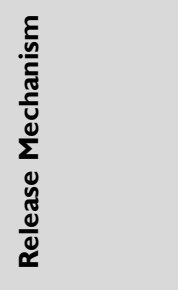 & & $\begin{array}{l}0 \\
\stackrel{0}{0}\end{array}$ & $\begin{array}{l}0 \\
\text { Lे } \\
z\end{array}$ & 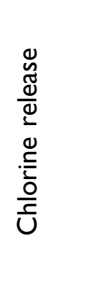 & 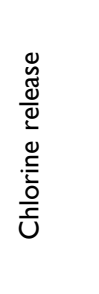 & 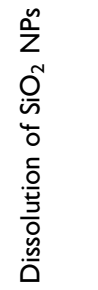 & 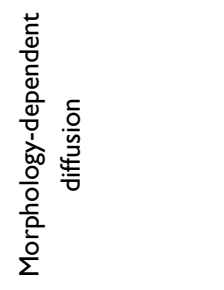 & 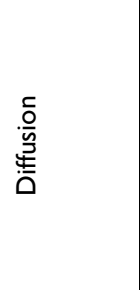 & 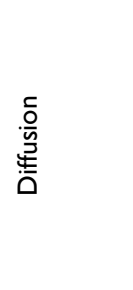 & 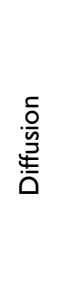 & 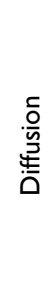 \\
\hline 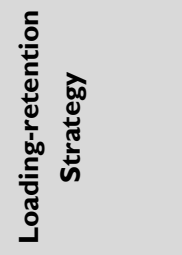 & & 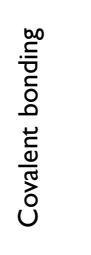 & 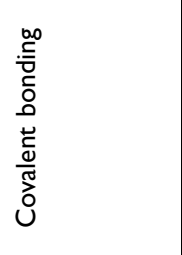 & 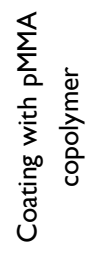 & 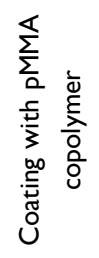 & 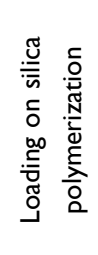 & 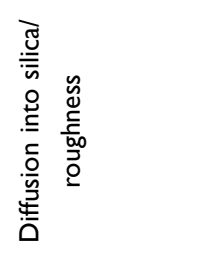 & 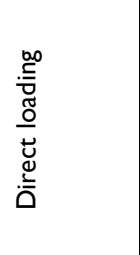 & 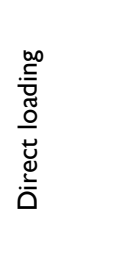 & 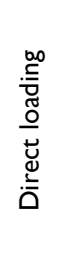 & 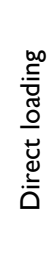 \\
\hline 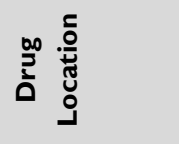 & & $\begin{array}{l}\stackrel{\mathscr{U}}{\mathscr{W}} \\
\stackrel{5}{5}\end{array}$ & $\begin{array}{l}\stackrel{\mathscr{J}}{\mathscr{\varpi}} \\
\stackrel{5}{5}\end{array}$ & 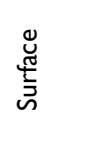 & 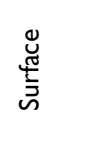 & 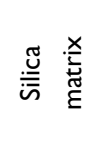 & 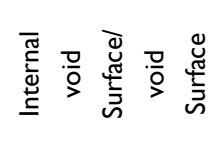 & 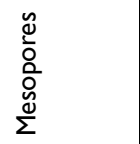 & 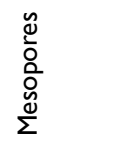 & 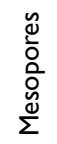 & 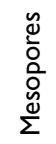 \\
\hline 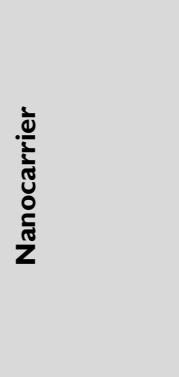 & & $\sum_{\sum}^{n}$ & $\sum_{\Sigma}^{n}$ & $\begin{array}{l}\stackrel{0}{Z} \\
\stackrel{\widetilde{U}}{\overline{\bar{n}}}\end{array}$ & 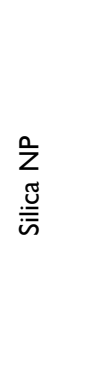 & 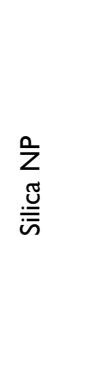 & 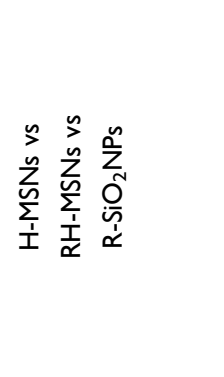 & 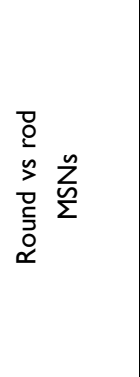 & 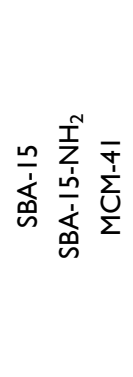 & 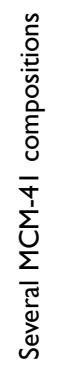 & 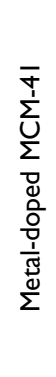 \\
\hline 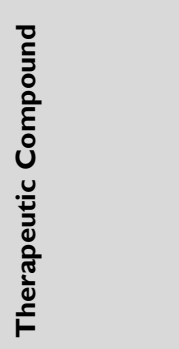 & 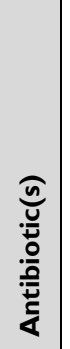 & 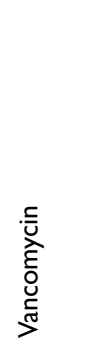 & 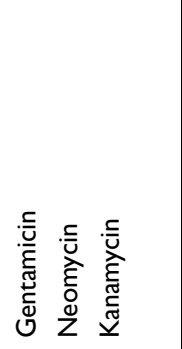 & 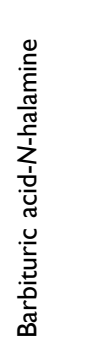 & 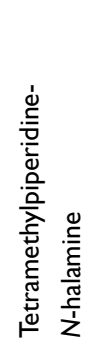 & 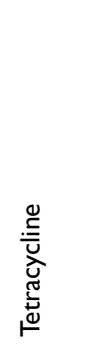 & 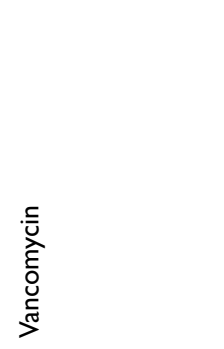 & 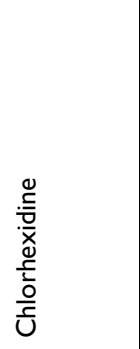 & 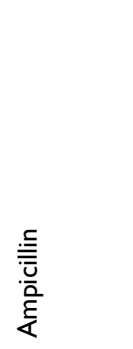 & 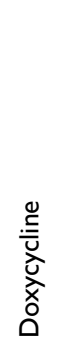 & 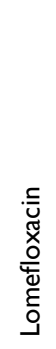 \\
\hline
\end{tabular}




\begin{tabular}{|c|c|c|c|c|c|c|c|c|c|c|c|c|}
\hline 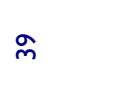 & 우 & $\frac{\mathfrak{q}}{q}$ & ₹ & ஜ & $\stackrel{+}{+}$ & $\hat{f}$ & $q$ & 오 & $\stackrel{\infty}{+}$ & กี & $\tilde{n}$ & 苞 \\
\hline $\begin{array}{l}\stackrel{0}{0} \\
\text { Z }\end{array}$ & $\begin{array}{l}\stackrel{0}{0} \\
\stackrel{0}{Z}\end{array}$ & $\begin{array}{l}\stackrel{0}{0} \\
\text { Z }\end{array}$ & $\begin{array}{l}\stackrel{0}{0} \\
\stackrel{0}{Z}\end{array}$ & $\begin{array}{l}\stackrel{0}{0} \\
\stackrel{0}{z}\end{array}$ & $\begin{array}{l}\stackrel{0}{0} \\
\stackrel{0}{z}\end{array}$ & $\begin{array}{l}\stackrel{0}{0} \\
\stackrel{0}{Z}\end{array}$ & 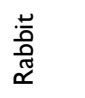 & $\begin{array}{l}\stackrel{0}{0} \\
\text { Ż }\end{array}$ & $\begin{array}{l}\stackrel{0}{0} \\
\stackrel{0}{Z}\end{array}$ & $\begin{array}{l}0 \\
\stackrel{0}{0} \\
\sum\end{array}$ & $\begin{array}{l}0 \\
\stackrel{0}{0} \\
\sum\end{array}$ & $\begin{array}{l}0 \\
\stackrel{0}{0} \\
\sum\end{array}$ \\
\hline 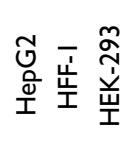 & 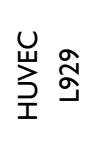 & 芦 & శ్ & $\frac{\stackrel{m}{\tilde{O}}}{\Sigma}$ & $\begin{array}{l}\stackrel{0}{0} \\
\text { ¿̇ }\end{array}$ & $\begin{array}{l}\stackrel{0}{0} \\
\text { ż }\end{array}$ & 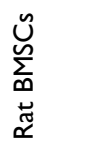 & $\begin{array}{l}0 \\
\stackrel{0}{0} \\
z\end{array}$ & $\begin{array}{l}\bar{\varpi} \\
\stackrel{\tilde{\mu}}{\rho} \\
\frac{0}{\Sigma}\end{array}$ & 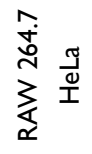 & 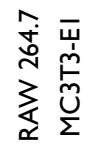 & 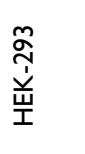 \\
\hline 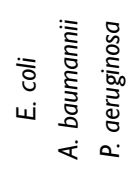 & 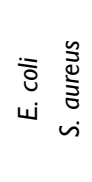 & 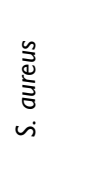 & 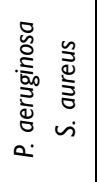 & 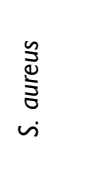 & 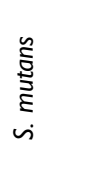 & 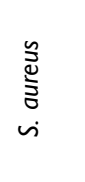 & 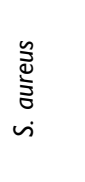 & $\begin{array}{l}\overline{\bar{z}} \\
\dot{\omega}\end{array}$ & 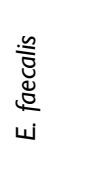 & 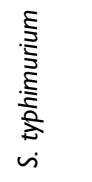 & 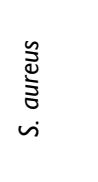 & 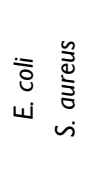 \\
\hline 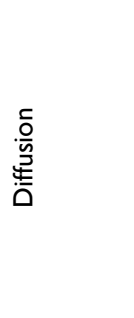 & 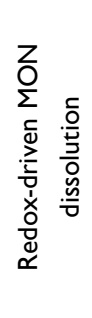 & 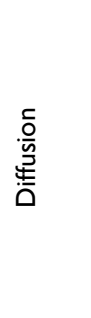 & 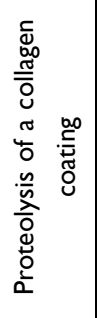 & 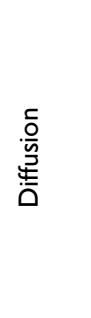 & 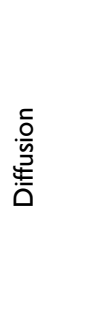 & 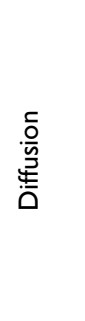 & 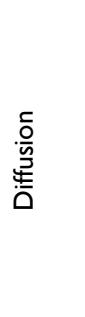 & 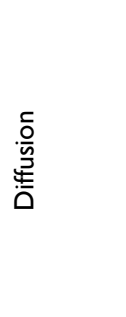 & 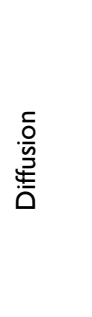 & 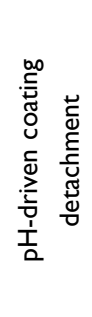 & 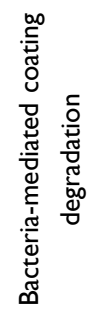 & 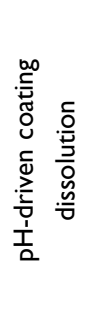 \\
\hline 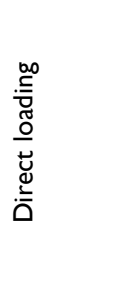 & 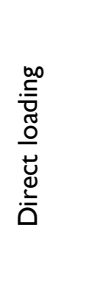 & 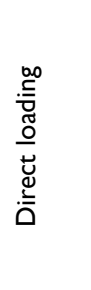 & 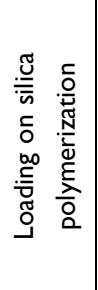 & 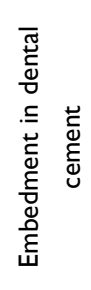 & 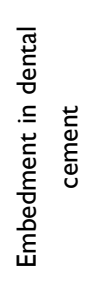 & 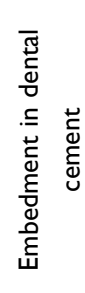 & 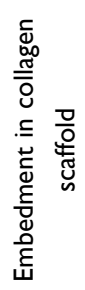 & 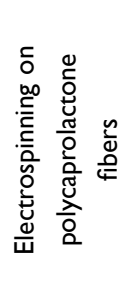 & 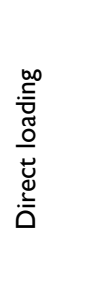 & 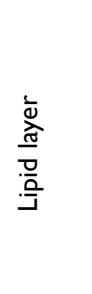 & 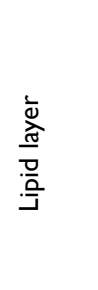 & 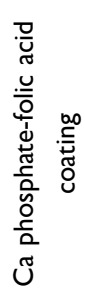 \\
\hline 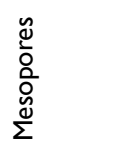 & 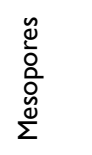 & 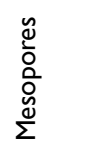 & 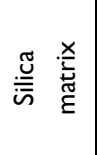 & 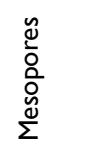 & 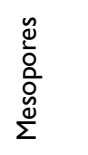 & 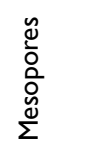 & 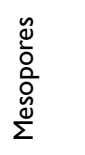 & 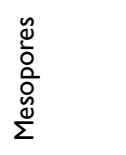 & 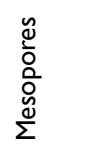 & 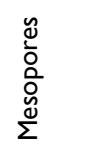 & 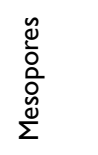 & 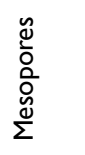 \\
\hline 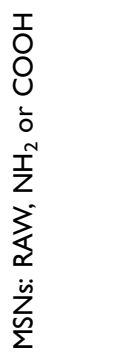 & $\begin{array}{l}\sum_{0}^{n} \\
\frac{0}{\Sigma}\end{array}$ & 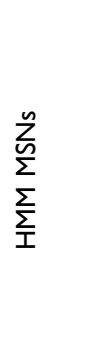 & $\begin{array}{l}\frac{n}{z} \\
0^{n}\end{array}$ & $\sum_{\Sigma}^{n}$ & $\sum_{\sum}^{n}$ & $\sum_{\Sigma}^{n}$ & $\sum_{\sum}^{n}$ & 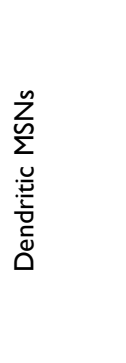 & 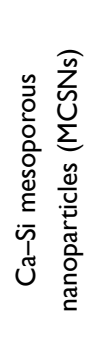 & $\sum_{\sum}^{n}$ & $\sum_{\Sigma}^{n}$ & $\sum_{\sum}^{n}$ \\
\hline $\begin{array}{l}\infty \\
. \bar{x} \\
\text { ลे } \\
\text { 흥 }\end{array}$ & 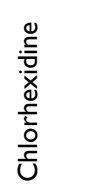 & 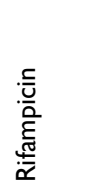 & 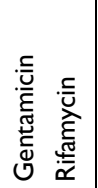 & 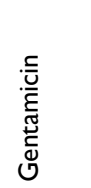 & 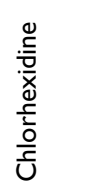 & 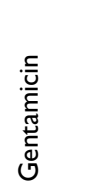 & 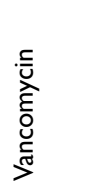 & 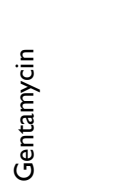 & 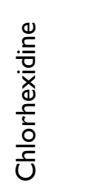 & 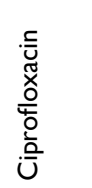 & 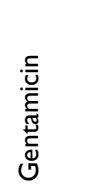 & 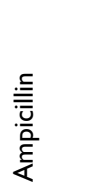 \\
\hline
\end{tabular}




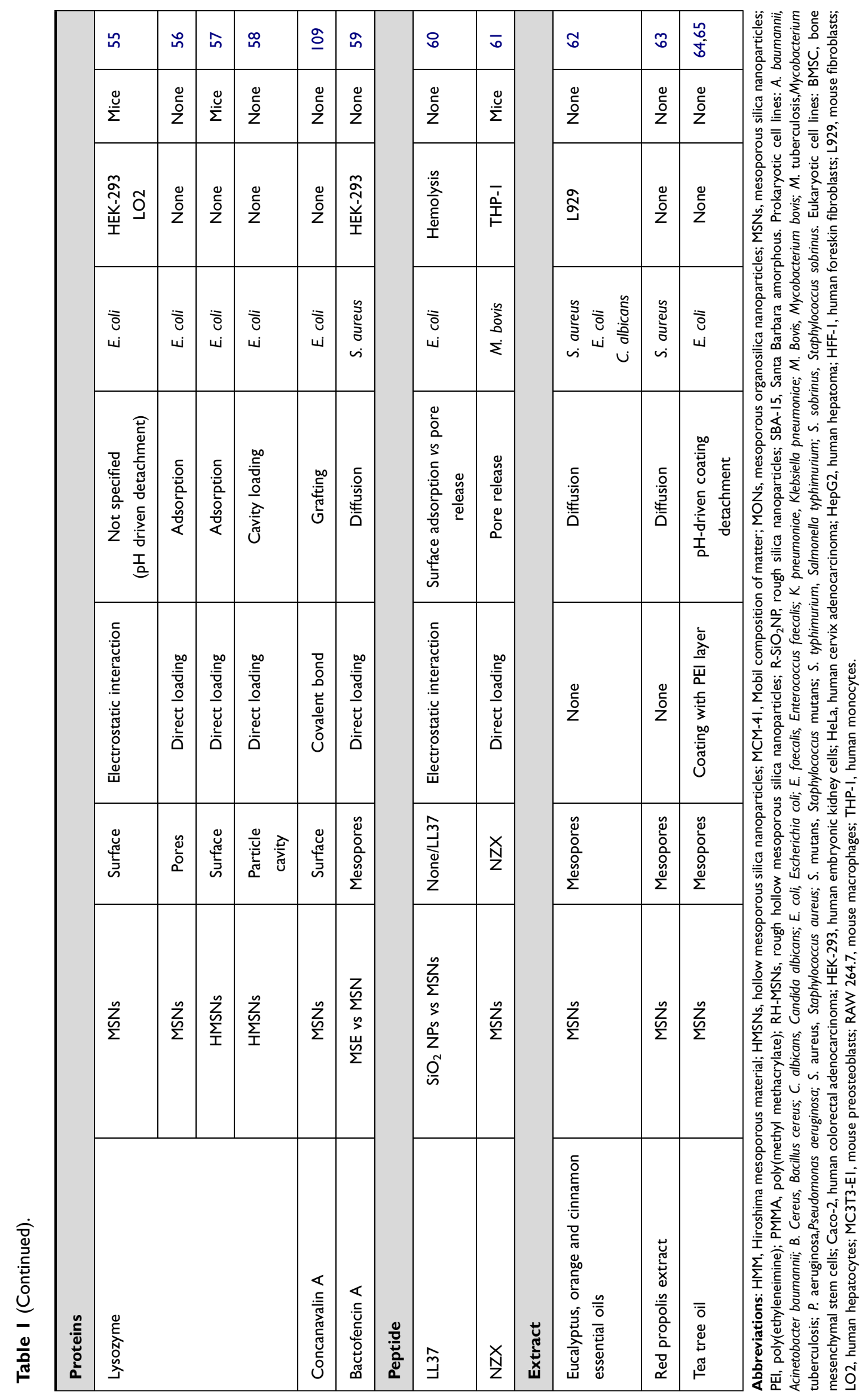


bacteria after eight hours (vancomycin dosage 25 $\mu \mathrm{g} \mathrm{mL} \mathrm{m}^{-1}$ ), while H-MSNs permitted bacterial regrowth due to an incomplete bacterial destruction. (Table 1)

In another approach to the topic, Li et al studied the effect on the morphology and size of silica nanosystems (rounded vs rod-like nanoparticles) on the delivery of chlorhexidine to several bacterial lines (Streptococcus sobrinus, Streptococcus mutans and C. albicans). ${ }^{35}$ From their studies, it is demonstrated that nonmodified MSNs were able to adhere better onto bacterial walls as a consequence of the interaction between the negatively charged silica and peptidoglycans therein. Regarding particle size these authors found that even with the same functionalization, larger particles (over $100 \mathrm{~nm}$ ) were unable to diffuse into the cytoplasm, causing not only damage at the bacterial walls, but also not a complete antibiotic effect. Regarding chemical functionalization of MSNs, two independent studies by Nairi et $\mathrm{al}^{36}$ and Deaconu et $\mathrm{al}^{37}$ set the basis for the optimal surface and pore modification for the delivery of two different antibiotics. In the first, although without a direct evaluation on bacteria, Nairi et al studied the differences in loading and release of ampicillin from three different silica compositions: SBA-15, amino-modified SBA-15 and MCM-41, ${ }^{36}$ finding that the amino modification was the best as it achieved a more sustained release profiles. In the second contribution the authors studied the effect of chemical modification onto different MCM-41-like MSNs on the delivery of doxycycline. To do so, the authors prepared several sets of nanoparticles including the following chemical modifications: phenyl, thiol, sulfonate, $\mathrm{Mg}^{+2}$ doping, calcined MCM-41, extracted MCM-41, and commercially available MCM-41. ${ }^{37}$ From the data obtained, the authors discovered that for this particular cationic antibiotic, the slowest release curves were obtained with either phenyl or thiol functionalization and Mg-doping. This behavior could be explained by considering the chemical structure of the employed drug that enables favorable interactions between phenyl groups at the silica with the fused rings on the drug and the chelation of $\mathrm{Mg}$ cations by hydroxyl groups (up to five) present on that particular molecule. Unfortunately, although the antibiotic effect of the drug loaded into silica did not reach the efficacy levels of free drug in a petri dish, it is interesting to know how to modify the silica to obtain improved release profiles. In a more recent contribution, these same authors also studied the effect of several metal-containing MCM-41 nanosystems on the loading and release of lomefloxacin hydrochloride. ${ }^{38}$ Herein, as expected, the presence of cations $\left(\mathrm{Mg}^{2+}, \mathrm{Fe}^{2+}, \mathrm{Ce}^{3+}\right.$, and $\left.\mathrm{Zn}^{2+}\right)$ onto the mesopore walls increased the interaction with the antibiotic, slowing down the release kinetics. Among all the metals tested, the most sustained releases were obtained with $\mathrm{Mg}^{2+}$, that together with $\mathrm{Zn}^{2+}$ were the only two systems in which silica remained significantly unaltered. (Table 1)

The chemical modification of silica nanoparticles is also an interesting possibility to tune drug release processes. Along this line Gounani et al, evaluated the release profile of polymyxin B from MSNs between 50 and 100 $\mathrm{nm}$. For their study the authors employed untreated, amino modified and carboxylate-modified MSNs. ${ }^{39}$ From their extensive experiments against three human cell lines, it could be established that all nanosystems had high biocompatibility (up to $80 \%$ cell survival with $1500 \mu \mathrm{g} / \mathrm{mL}$ nanoparticles) on human HepG2, HEK-293 and HFF-1 cell lines; being the negatively charged MSNs, the particles that affected the viability less. Regarding the antibacterial effect, all nanoparticles behaved similarly, finding values for MIC and minimum biocidal concentrations (MBCs) between 1-2 and 2-4 $\mu \mathrm{g} / \mathrm{mL}$, respectively for all bacteria tested. Apart from chemical modifications, which are aimed at modifying the interactions between cargoes and carriers, another interesting possibility is to modify the dissolution rates of the carrier itself to enhance drug release. This strategy was successfully employed by $\mathrm{He}$ et al, who prepared mesoporous organosilica nanoparticles (MONs) bridged with tetrasulfide bonds with chlorhexidine as the template ${ }^{40}$ in order to prepare a nanosystem able to dissolve in metabolically active microenvironments. As a result, their chlorhexidine-loaded MONs had a superior release of the antibiotic under the presence of glutathione (GSH) that achieved complete drug release within four days. This system was proven to destroy tested bacteria and prevent biofilm formation while maintaining good cell viabilities (HUVEC and L929) above the typical values obtained for free chlorhexidine.

In another interesting set of contributions, Subramaniam et al and Joyce et al evaluated the behavior between MSNs with different particle sizes ${ }^{41}$ and surface functionalization $^{42}$ to be tested on $S$. aureus intracellular infections. In these contributions the authors employed Hiroshima mesoporous materials (HMM) with sizes in the range of $40-100 \mathrm{~nm}$ and rifampicin as antibiotic cargo. Unfortunately, despite the outstanding biocompatibility of the nanosystem, the antibiotic effect was very limited as it had very little internalization within 
macrophages. Hence, to improve the efficacy the authors studied the role of surface chemistry of these HMM MSNs by varying the template extraction process. Indeed, the MSNs with higher silanol concentration at the surface proved to have higher internalization (twofold) into Caco-2 adenocarcinoma cells. Although this implementation is an advance toward more precise nanosystems, it does not seem to be enough to develop an effective antiinfective nanosystem for intracellular infections according to the data shown. ${ }^{43}$

\section{Silica-containing Composites on Antibiotic Delivery}

The high chemical stability of silica together with the protection offered by its mesoporous structures has permitted us to develop hybrid materials in which several features could be combined. For instance, Álvarez et al reported a composite device in which antibiotic-loaded silica nanoparticles were embedded within collagen hydrogels. ${ }^{44}$ As a result, the system was able to prevent bacterial infections thanks to the sustained delivery of antibiotic (gentamicin or rifampicin) while the outer collagen layer aided in the healing of chronic wounds. To build this system, antibiotic-loaded $\mathrm{SiO}_{2} \mathrm{NPs}$ prepared in situ from TEOS and ammonia in the presence of antibiotics and were coated with a collagen layer afterward. As a result, the system had a fivefold increased biocompatibility on fibroblast cell cultures than the raw antibioticloaded particles while maintaining the antibacterial effect.

Employing a similar strategy the use of antibioticloaded, nanostructures with silica nanoparticles as components for hybrid bone cement composites have been reported. Shen et al pioneered the development of bone cements with antibiotic properties. ${ }^{45}$ In their first contribution the authors prepared poly(methyl methacrylate)-based bone cements reinforced with gentamicin-loaded SBA-15 mesoporous silica. As a result, the complete system showed a long-lasting drug delivery without affecting the mechanical properties of the cement. The in vitro evaluation of this system on mouse fibroblast cultures showed an outstanding biocompatibility, opening the way to the in vivo application of such antibiotic-loaded silicapolymer composites. In addition to the former example, Yan et al also studied the role of chlorhexidine-loaded MSNs as components of a glass ionomer composite cement. ${ }^{46}$ In their research the authors found that the resulting material was able to destroy $S$. mutans' biofilms without affecting the mechanical properties of the reinforced silica-alumina cement. It is also interesting to remark that loadings of about $1 \%$ chlorhexidine (approx. $1 \mathrm{mg}$ antibiotic per $\mathrm{cm}^{2}$ in the cement) obtained a highly sustained release able to prevent biofilm formation for up to 30 days, increasing the shelf-live of the traditional glass ionomer cement. Similar results were obtained on the research conducted by Letchmanan et al who also employed antibiotic-loaded MSNs into as reinforcement in acrylic dental cements. ${ }^{47}$ In their investigations the authors assessed an antibacterial effect of their reinforced cements of about four weeks employing a material with a $2.72 \%$ gentamicin loading. Another interesting formulation suitable for dental applications was reported by Fan et al, who employed chlorhexidine-loaded Ca-Si mesoporous nanoparticles to avoid infection in implants while enabling bone remineralization. ${ }^{48}$ Their system showed antibiotic effect against planktonic Enterococcus faecalis without significant effect on the proliferation of murine preosteoblasts even at low concentrations. Moreover, when applied on dentin slices, the use of this nanodevice promoted an effective mineralization due to the creation of hydroxyapatite nanocrystals at the dentin, enabling intradental treatment of infected bone.

Apart from biomaterials aimed at dental applications, other biomaterials reinforced with antibiotic-loaded MSNs have also been successfully prepared. For instance, aiming at bone repairing, Zhou et al employed vancomycin-loaded MSNs embedded into a gelatin scaffold to repair infected bone defects in rabbits. ${ }^{49}$ As a result, the prepared composite prevented infection and permitted us to recover mineral density and bone volume much faster than the raw gelatin scaffold or the hybrid material without the antibiotic. For interested readers, a very recent review by our group covers this topic in detail. ${ }^{7}$ Another successful combination was reported by Chen et al, who modified polycaprolactone fibers with gentamycin-loaded dendritic MSNs by electrospinning. ${ }^{50}$ As a result, the MSNcontaining nanosystem proved to have a longer and more sustained release than the gentamycin-loaded polycaprolactone, providing an antibiotic effect able to prevent bacteria colonization according to the sensitivity test shown.

Another interesting family of candidates for drug delivery are lipid-coated nanosystems. Those, apart from preventing undesired drug leakages, also provide an outstanding biocompatibility. ${ }^{51}$ Following this strategy, several examples of drug delivery systems could be found in the literature. For example, Mudakavi et al 
designed lipid-coated mesoporous silica nanoparticles as an oral delivery system for the targeting and treatment of intravacuolar Salmonella infections. ${ }^{52}$ To do so, the authors employed MSNs with sizes between 50 and 100 $\mathrm{nm}$ and a lipid coat of approximately $5 \mathrm{~nm}$ thickness obtained upon sonication of liposomes. To provoke infection, bacteria were ingested and monitored on M-cells and dendritic cells present in the Peyer's patches in the small intestine, where these bacteria employ a clever molecular machinery to invade the gut epithelial barrier. Once inside, the bacteria replicate inside the host cell in specialized vacuoles called Salmonella-containing vacuoles (SCV), evading the immune system. When the authors tested the efficacy of their drug-loaded, lipid-coated MSNs, they found a high $\mathrm{pH}$ dependence on ciprofloxacin release, which suggest a preferential release in the stomach rather than in the gut. However, the outstanding biocompatibility showed by that the lipid layer permitted delivery of this nanosystem to the gut to treat the infection. Although the delivery mechanism to SCVs is not fully clear, the better performance of nanoparticulate antibiotic suggests that such a coating may also have some targeting abilities. A similar design was employed by Tang et al to create a nanosystem able to treat intracellular infections caused by $S$. aureus. ${ }^{53}$ Their system, based on lipid-coated, gentamicin-loaded MSNs also included the ubiquicidin (UBI ${ }_{29-41}$ ) bacteria-targeting peptide to ensure an adequate drug delivery. In addition, the coating lipid layer was also engineered to be dismantled in the presence of metabolically active bacteria. As a result, the system was able to enter murine fibroblasts and preosteoblasts, two possible reservoirs of bacteria in mammals and reduce tissue infection and inflammation according to the values of IL- 6 and TNF- $\alpha$ reported in the immunohistochemical assay.

In addition to lipid layers, some authors have also developed alternative coating strategies with outstanding biocompatibilities. Such is the case of the nanosystem reported by Chen et al who coated ampicillin-loaded MSNs with a biomineral calcium phosphate $(\mathrm{CaP})$ layer to prevent $E$. coli and $S$. aureus infections in mice. ${ }^{54}$ To prepare the nanocarrier the authors employed folic acid (FA), which, apart from providing targeting capabilities, also favored the biomineralization process. The resulting ampicillin-loaded MSN@FA@CaP@FA composite proved to have more antibacterial effect than the free antibiotic against both bacteria, although $E$. was much more sensitive than $S$. aureus. The authors also tested their system in mice, finding that it was able to inhibit cutaneous infections when the nanosystem was applied in a topic band formulation. This case obtained a $100 \%$ survival of the mice with a dose of $1 \mathrm{mg} / \mathrm{kg}$, although unfortunately, no data were given about biodistribution upon systemic injection or about oral administration.

\section{Delivery of Antibiotic Proteins}

In addition to typical antibiotics, there have been reports of the use of silica particles with suitable mesopores for the delivery of proteins with antibiotic properties. As reviewed in a previous contribution by us, ${ }^{21}$ most examples are reported with lysozyme, which is able to hydrolyze grampositive bacterial walls by cleaving the $\beta-1,4$ bonds between $N$-acetylmuramic acid and $N$-acetyl$D$-glucosamine.

Herein, several approaches for the delivery of lysozyme-containing systems can be found in the literature. For instance, in the first example by Li and Wang a direct electrostatic interaction was employed to bind the protein to negatively charged surfaces of MCM-41 MSNs. ${ }^{55}$ This approach, with exposed proteins, permitted the authors to build a stable corona capable of killing both gram-positive and negative bacteria due to the release of a protein which was able to exert a hydrolytic enzymatic activity onto glucosides. Despite the antibacterial effect demonstrated, the absence of an efficient enzyme protection prevented the system from achieving sustained effects.

Based on this particular combination of silica and lysozyme, more recent models improved the antibiotic performance by including protective features and increased loading capacity of carriers. For example, Wang's and Song's groups attempted to augment the antibacterial effect by enlarged dendritic mesoporous particles $^{56}$ and a structured silica with rough surface called nanopollens, ${ }^{57}$ respectively. From their studies, it could be assessed that the rougher the surface, the better the protein loading. Moreover, both silica carriers were able to preserve the enzymatic activity within acceptable levels, thus maintaining the antibacterial effect. In a direct comparison between both approaches, it could be appreciated that the engineered nanopollens provided a more sustained release that increased the long-term antibiotic effect, although only on planktonic bacteria. In another contribution, $\mathrm{Xu}$ et al tested silica-carried lysozyme against a formed biofilm. ${ }^{58}$ For this work the authors employed enlarged pore, hollow MSNs with a loading capacity of about $350 \mathrm{mg} / \mathrm{g}$. At this point, it is interesting to remark that 
the use of the chosen silica carrier produced a highly sustained release able to boost the antibacterial effect above the maximal activity of free lysozyme (reached at $400 \mu \mathrm{g} / \mathrm{mL}$ ), demonstrating once again that drug delivery usually improves the pharmacological effect of free drugs.

Regarding other proteins with antibiotic effect, not many examples could be found in the literature. Along this line, in an very recent example by us, we demonstrated the antibacterial effects of the concanavalin A (ConA) protein in combination with levofloxacin, a typical antibiotic. ${ }^{59}$ In this example, to combine both antibiotic species we employed carboxylate-modified MSNs, which were loaded with levofloxacin and functionalized with ConA upon drug loading. The effect of this dual-action nanosystem permitted us to achieve a complete destruction of the E. coli biofilm even at minimal concentrations $(10 \mu \mathrm{g}$ MSNs per $\mathrm{mL})$, improving any of the precedent models and showing that combination therapy usually improves treatments with single-drug delivery systems. ${ }^{17,18}$

In addition, in a contribution by Durack et al bactofencin A also demonstrated an interesting antibiotic effect when loaded into mesoporous matrices. ${ }^{59}$ In this work the authors evaluated the performance of such protein when loaded into SBA-15 porous solids against $S$. aureus. Unfortunately, in this case the absence of gated pores permitted a fast diffusion of protein that led to an almost complete release within five hours, which prevented a long-lasting effect as the OD of bacterial culture was recovered quickly. Nevertheless, this proof of concept also demonstrated that a sustained protein release was enough to improve the overall antibacterial effect. Besides the previous reported examples, there are also other interesting proteins that may be suitable for the development of antibiotic nanotherapeutics in the near future. Such is the case of lactoferrin, as already developed by several research groups and employed for other purposes as postulated by us in a previous contribution. ${ }^{21}$

\section{Delivery of Antibacterial Peptides}

Despite the potential of certain peptide sequences as antibacterial drugs, the fact is that peptides have been very poorly exploited as cargoes for silica nanocarriers. ${ }^{21}$ Among the examples reported, it could be highlighted by the contribution by Braun et al who adsorbed the LL37 (LLGDFFRKSKEKIGKEFKRIVQRIKDFLRNLVPRTE-

S) cationic antibacterial peptide onto several surfacemodified silica nanoparticles (nonporous, calcined mesoporous and amino-capped mesoporous). ${ }^{60}$ Unfortunately, although loading of the LL-37 peptide onto nanoparticles' surfaces improved the pharmacological profile of the free peptide, it still showed significant hemolysis, which prevented its use in typical applications in vivo. Nevertheless, the system could be improved by the use of other nanocarriers, such as those described above, able to fully cloak the peptide's cationic charge.

As introduced above, the treatment of infected cells, especially blood cells, is one of the biggest challenges to face in future medicine that could be overcome by using nanotechnological approaches. In the example by Tenland et al a delivery system was employed to treat infected macrophages. ${ }^{61}$ Herein the known NZX (GFGCNGPWSEDDIQCHNHCKSIKGYKGGYCARGGFVCKCY) peptide could be successfully threaded within the silica mesopores to create a nanosystem able to prevent hemolytic damage. As a consequence, the nanocarrier was able to internalize into macrophages and once there produce a sustained release able to exert a long-term antituberculosis effect without comprising the survival of treated macrophages and create antituberculosis reservoirs at the formed intracellular vacuoles.

\section{Delivery of Other Compounds with}

\section{Antibiotic Properties: Plant Extracts}

In addition to the typical drugs, peptides and proteins, also of interest is the response of bacteria against certain antibiotic compounds present on vegetal extracts. Along this line, Balaure et al studied the effect of three essential oils: eucalyptus (EUC), orange (ORA), and cinnamon (CIN), against clinically relevant species ( $S$. aureus, E. coli and Candida albicans) and against the L929 mouse fibroblast cell line to ensure biocompatibility. ${ }^{62}$ The loading of the corresponding essential oil into MSNs were carried out with the aid of a grinding mortar employing chloroform as a volatile additive capable of favoring the loading process thanks to a reduction of the oil viscosity and a facile evaporation. The resulting oil-loaded MSNs showed a significant antibacterial bias depending on the bacteria to treat and the oil employed. The best inhibitory effects were obtained for C. albicans when the MSNs loaded with eucalyptus oil were employed, while for $S$. aureus orange oil performed the best. In the case of $E$. coli, although cinnamon oil provoked certain inhibition that was far away from the activity showed by other oil-loaded MSNs. In any case, all combinations showed interesting effects on the 
reduction of biofilm formation, which were significant in particle concentrations near $1 \mu \mathrm{g} / \mathrm{mL}$.

Beyond the previous pioneering contribution, during the last year several articles have reported the loading of plant extracts with interesting antibacterial properties. Such is the example reported by de Azevedo et al, who reported a nanosystem loaded with red propolis with proven antibacterial effect onto $S$. aureus $^{63}$ or the nanosystem reported by Zhou et al who employed tea tree oil as pore-loaded antimicrobial agent against E. coli. ${ }^{64,65}$ Nevertheless, in this last example, the authors employed a very convenient poly(ethyleneimine) (PEI) coating to prevent undesired oil leakage. However, as commented below, the use of cationic species on cells have a well demonstrated membrane-lytic effect; which could affect the overall antibacterial effect of the system throughout a nonstudied combined effect of the added plant extract oil and PEI which may diffuse together along the bacterial culture.

\section{Behavior of Polyionic MSNs Against Bacteria and Biofilms Antibiotic Effect of Polycation-modified Silica Nanoparticles}

All kind of cells base their membranes on phospholipid bilayers. This fact make these structures highly sensitive to polycations and cationic surfactants, which are able to produce membrane-lytic processes able to provoke cell death (Figure 2).
As expected, this strategy is mostly suitable for the disinfection of surfaces and materials, but inadequate for living organisms because cationic compounds produce high hemolysis rates leading to thrombus that may compromise overall survival. Therefore, to overcome this limitation several nanotechnological approaches have been tested in order to limit the undesired action of cationic species in vivo. In the first example on the topic, Trewyn et al reported imidazolium-based ionic liquids as antibiotic compounds. ${ }^{66}$ Unfortunately, although these compounds were successfully loaded within the mesopores and the system was able to produce a bacterial growth inhibition, the noncontrolled release and the highly toxic nondegradable cargo prevented their evaluation in eukaryotic cells; although their report set the basis for the delivery of antibacterial polycations. Nevertheless, the application of polycation-containing MSNs is of interest to prevent the biological colonization of materials and surfaces. For instance, an interesting example on the topic is the contribution by Wang et al, who prepared hybrid composites by layer by layer assemblies of negatively charged montmorillonite and ammonium-modified silica nanoparticles. ${ }^{67}$ As a result, their system was able to fully destroy gram-positive and gram-negative bacteria due to the quaternary ammonium-modified MSNs. In addition to the former, Michailidis et al reported a parallel strategy to coat MCM-48 MSNs with C-18 and C-14 alkyl substituted quaternary ammonium salts, although in their

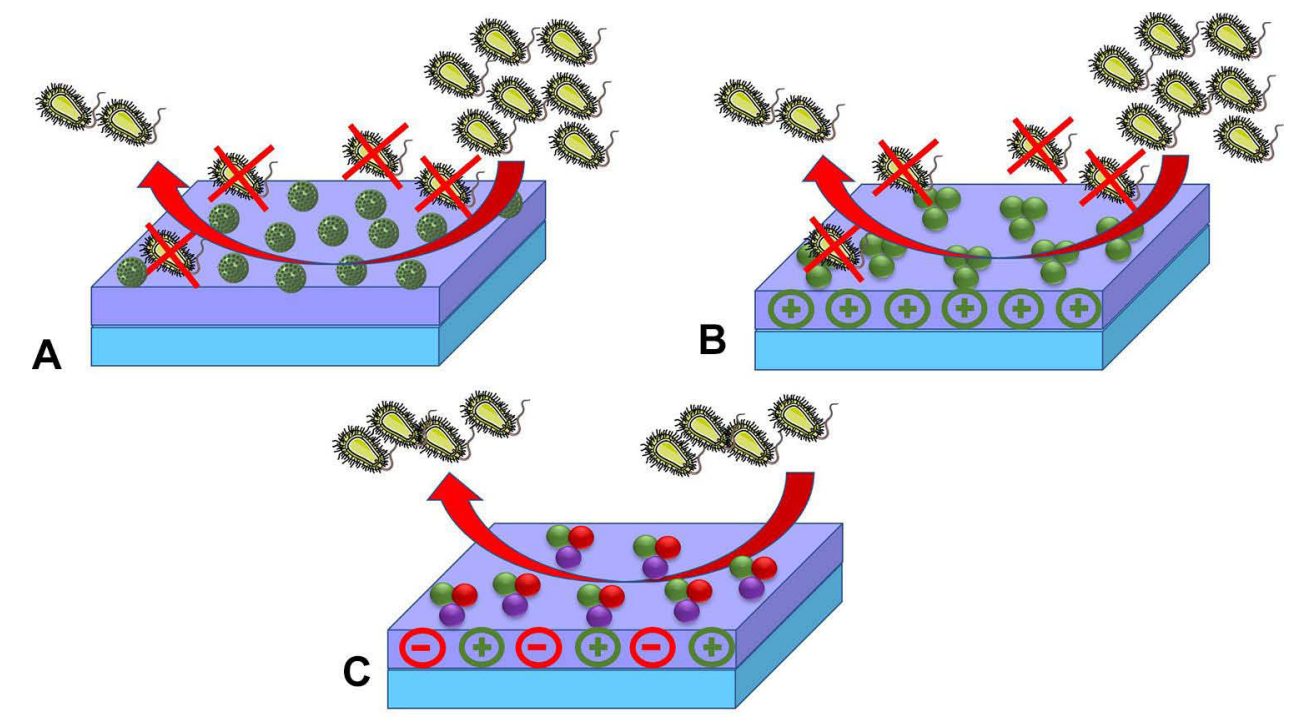

Figure 2 Strategies to convert silica-containing materials into antibiotic nanodevices by modifying their structure with polyionic species. (A) Loading and release of biocidal (cationic) species within mesopores. (B) Surface functionalization with polycations to induce bacterial destruction throughout membrane-lytic processes. (C) Prevention of adhesion and/or biofilm formation by modifying the surface with zwitterion-containing structures. 
example a broad range biocide (Parmetol S15) was loaded into the mesopores. As a result, the authors were able to obtain a surface able to resist the bacterial (and other organisms) colonization of these materials in sea water for more than five months, proving the potential antibacterial effect of combining antibiotic delivery with membrane-lytic features (Table 2). A similar effect was also reported by Bai et al, who found a good antibiotic effect against E. coli, $S$. aureus and $P$. gingivalis employing hollow MSNs decorated with C-18 alkyl substituted quaternary ammonium salts and loaded with metronidazole. ${ }^{68}$
Although the use of permanent cations such as tetraalkylammonium halides exhibits unbeatable antibacterial effects, they are usually poorly recommended for preventing infections in the presence of eukaryotic cells and living organisms due to the high membrane and hemolysis rates showed by these permanent cations. In order to reduce such effects, it is highly convenient to employ $\mathrm{pH}-$ dependent amino-enriched moieties such as lysineenriched polypeptides. Along this line, Velikova et al reported the use of $\varepsilon$-poly-L-lysine capping as an antibacterial sensitizer to enhance the antibiotic effect of histidine

Table 2 Silica-based Porous Nanosystems with Antibacterial Properties

\begin{tabular}{|c|c|c|c|c|c|c|c|c|}
\hline $\begin{array}{l}\text { Silica } \\
\text { Nanocarrier }\end{array}$ & $\begin{array}{l}\text { Antibacterial } \\
\text { Component }\end{array}$ & $\begin{array}{c}\text { Primary } \\
\text { Action } \\
\text { Mechanism }\end{array}$ & $\begin{array}{l}\text { Antibiotic } \\
\text { Species } \\
\text { Loading }\end{array}$ & $\begin{array}{c}\text { Antibiotic Species } \\
\text { Release } \\
\text { Mechanism }\end{array}$ & $\begin{array}{c}\text { In vitro } \\
\text { Evaluation } \\
\text { (bacteria) }\end{array}$ & $\begin{array}{c}\text { In vitro } \\
\text { Evaluation } \\
\text { (Eukaryotic } \\
\text { Cells) }\end{array}$ & in vivo & Ref. \\
\hline \multicolumn{9}{|c|}{ Silica system modified with poly-ions. } \\
\hline MSNs & lonic liquids & $\begin{array}{c}\text { Membrane } \\
\text { lysis }\end{array}$ & None & None & E. coli & None & None & 66 \\
\hline MMT-MSN & $\begin{array}{l}\text { D-CI8- } \\
\text { TMSACI }\end{array}$ & $\begin{array}{c}\text { Membrane } \\
\text { lysis } \\
\text { Water- } \\
\text { repellant }\end{array}$ & None & None & $\begin{array}{c}\text { E. coli } \\
\text { S. aureus }\end{array}$ & None & None & 67 \\
\hline $\begin{array}{l}\text { MCM-48 } \\
M S N\end{array}$ & $\begin{array}{l}\text { D-CI8- } \\
\text { TMSACl } \\
\text { D-CI4- } \\
\text { TMSACI }\end{array}$ & $\begin{array}{l}\text { Membrane } \\
\text { lysis } \\
\text { Biocidal }\end{array}$ & Parmetol SI5 & None & Sea bacteria & Sea cells & None & 110 \\
\hline HMSNs & $\begin{array}{l}\text { D-CI8- } \\
\text { TMSACl }\end{array}$ & $\begin{array}{l}\text { Membrane } \\
\text { lysis } \\
\text { Biocidal }\end{array}$ & Metronidazole & None & $\begin{array}{l}\text { S. aureus, } \\
\text { E. coli } \\
\text { P. gingivalis }\end{array}$ & None & None & 68 \\
\hline $\begin{array}{l}\text { MCM-4I } \\
\text { MSNs }\end{array}$ & $\varepsilon$-poly-L-lysine & $\begin{array}{l}\text { Membrane } \\
\text { sensitizing }\end{array}$ & HKAI & $\begin{array}{l}\mathrm{pH} \text {-driven lysine } \\
\text { detachment }\end{array}$ & $\begin{array}{c}\text { E. coli } \\
\text { S. marcescens }\end{array}$ & Caco-2 & Zebrafish & 69 \\
\hline $\begin{array}{l}\text { MCM-4I } \\
\text { MSNs }\end{array}$ & DAMO & $\begin{array}{l}\text { Membrane } \\
\text { sensitizing }\end{array}$ & Levofloxacin & None & $\begin{array}{l}\text { E. coli } \\
\text { S. aureus }\end{array}$ & None & None & 70 \\
\hline $\begin{array}{l}\text { MCM-4I } \\
\text { MSNs }\end{array}$ & G3-PPI & $\begin{array}{l}\text { Membrane } \\
\text { sensitizing }\end{array}$ & Levofloxacin & None & $\begin{array}{l}\text { E. coli } \\
\text { S. aureus }\end{array}$ & None & None & 71 \\
\hline \multicolumn{9}{|c|}{ Zwitterion-modified silica nanosystems } \\
\hline SBA-15 MSNs & $\begin{array}{l}\text { APTES- } \\
\text { CEST-Na }\end{array}$ & Antifouling & None & None & E. coli & Saos-2 & None & 73 \\
\hline $\begin{array}{l}\text { MCM-4I } \\
\text { MSNs }\end{array}$ & APTS:THSMP & Antifouling & Levofloxacin & None & $\begin{array}{c}\text { E. coli } \\
\text { S. aureus }\end{array}$ & $\begin{array}{l}\text { RAW } 264.7 \\
\text { macrophages }\end{array}$ & None & 74 \\
\hline MSNs & TES-NMe ${ }_{2}-\mathrm{SO}_{3}$ & Antifouling & None & None & E. coli & None & None & 75 \\
\hline
\end{tabular}

Abbreviations: APTES, 3-aminopropyl triethoxysilane; CEST-Na, carboxyethyl silanetriol sodium salt; DAMO, N-(2-aminoethyl)-3- aminopropyltrimethoxysilane; D-Cl8TMSACl, dimethyloctadecyl [3-(trimethoxysilyl) propyl] ammonium chloride; D-Cl4-TMSACl, dimethyltetradecyl (3-(trimethoxysilyl)propyl) ammonium chloride; G3-PPI,

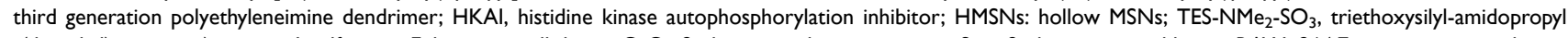
-(dimethyl)-ammonio)propane-I-sulfonate. Eukaryotic cell lines: CaCo-2, human colon carcinoma; Saos-2, human osteoblasts;; RAW 264.7, murine macrophages. Prokaryotic cell lines: E. coli, Escherichia coli; M. tuberculosis, Mycobacterium tuberculosis; P. gingivalis, Porphyromonas gingivalis; S. aureus, Staphylococcus aureus. 
kinase autophosphorylation inhibitors. ${ }^{69}$ IIn this model the authors employed carboxylate-modified MCM-41 MSNs into which were loaded several inhibitors. Herein the polylysine acted as a coating polymer and sensitizer against bacteria. According to the authors' claims, their system was able to prevent both gram-positive and negative bacteria while it permitted the treatment on mammalian cells as suggested by viability and immunotoxicity assays carried out on zebrafish.

The use of amine-modified MSNs as antibacterial agents has also been successfully reported by our group in several approaches. For instance, Pedraza et al demonstrated that adequately modified silica nanoparticles in combination with a pore-loaded conventional antibiotic was able to exert an outstanding antibacterial effect onto gram-positive and negative bacteria. ${ }^{70}$ Herein 2-aminoethyl-aminopropyl silane was emplyed to generate polycation coating in a broad range of $\mathrm{pH}$ due to the combination of primary and secondary amines onto the structure. In vitro results against $E$. coli and $S$. aureus showed that such combination of polycations and antibiotic was able to target bacteria and destroy preformed biofilms. In a subsequent contribution by us, González et al also evaluated the performance of polyamine-containing dendrimers as components for preparing nano-antibiotics able to combine drug delivery plus bacteria targeting and sensitization. ${ }^{71}$ This second approach obtained a double improvement of the original DAMO-modified MSNs; as on the one hand retention of levofloxacin was improved, while on the other hand, the increase on the number of ammonium cations enhanced the interaction of nanoparticles and bacteria.

However, despite the promising features of polycationic mesoporous nanoparticles as bacterial-targeted nanodevices for drug delivery, they would require extensive clinical tests to minimize the risks associated to the administration of polycations. For this reason, the use of polyions with a perfect charge balance has also been the subject of study. Nevertheless, as reviewed below, poly-zwitterions show different, although very interesting features.

\section{Antibiofilm Effect of Poly-ion Modified Silica Nanoparticles}

Apart from the antibiotic effect of polycationic species, zwitterionic poly-ions also exert an interesting antibacterial feature: the inhibition of adhesion onto surfaces and thus the prevention of biofilm formation. ${ }^{72}$ In comparison with other nanosystems, porous nanosilica has become a fantastic platform for the development of zwitterioncontaining nanosystems because of its high chemical compatibility and robustness (Figure 2). One of the first examples on the topic described the effect of modified SBA-15 nanoparticles with carboxylate, amino or a combination of both. As expected, the carboxylate-modified silica did not provide an effective antibacterial adhesion while the amino-terminated silica led to the expected antimicrobial effect based on the membrane-lytic effect. However, when the zwitterion-modified silica was employed, it obtained an adequately biocompatible system capable of preventing bacterial adhesion and biofilm development. ${ }^{73}$ More recently, this strategy was implemented onto MCM-41 MSNs, which due to the smaller pores have better drug release profiles for small molecules. ${ }^{74}$ In this model two implementations were made: the pores were loaded and the acid groups changed by more acidic moieties able to widen the $\mathrm{pH}$ range of zwitterion existence. As a result, the system was able to treat macrophages' infection thanks to an increased uptake and a similar biocompatibility to polyethylene modified nanoparticles.

More recently other research groups have evolved the zwitterion functionalization strategy by including permanent ions and molecules bearing zwitterionic structures that upon grafting ensure a perfect distribution of charges along the whole structure. In one very interesting contribution Knowles et al employed a silane-modified sulfobetaine (triethoxysilyl-amidopropyl-(dimethyl)-ammonio) propane-1-sulfonate) to turn raw silica particles into zwitterion-modified nanoparticles. ${ }^{75}$ Their approach maintained a successful anti-adhesive feature when tested at different $\mathrm{pH}$ and against several types of substrates: bacteria, proteins, and spores. However, despite these outstanding results, the authors did not maintain a permanent antifouling property due to a $\mathrm{pH}$-driven silica degradation that detached the outermost zwitterion functionalization. Nevertheless, instead of being a significant limitation this dissolution process enables the clearance of silica, improving its biocompatibility.

Indeed, the superior antifouling properties of zwitterion-coated silica particles have permitted us to implement such technology onto drug delivery and nanomedicine. For instance, Ji et al reported the use of a copolymer of polydopamine (PDA) and a betaine-modified polymer (poly (3-(3-methacrylamidopropyl-(dimethyl)-ammonio)propane-1-sulfonate)) to produce a silica-based nanosystem able to be stable up to $72 \mathrm{~h}$ into the most common media: PBS, BSA, and even FBS. ${ }^{76}$ In another example, 
Sanchez-Salcedo et al reported the use of 2-methacryloyloxyethyl phosphorylcholine as a zwitterion-incorporating agent, which could be grafted onto amines by a Michael reaction. ${ }^{77}$

\section{Antibacterial Effects of Metal-doped MSNs}

\section{Antibacterial Effects of Silver-silica Nanocomposites}

In addition to poly-ionic antibacterial nanodevices, another blooming field of research is the use of silica nanoparticles to deliver cations and metallic nanoparticles, specially of silver, able to promote bacterial death throughout an apoptosis-like mechanism. ${ }^{78-80}$ Nevertheless, although known for ages, this antibiotic mechanism is not fully understood and it could be triggered either with $\mathrm{Ag}$ colloids and $\mathrm{Ag}^{+}$ cations alike. ${ }^{81}$ For this reason, it is possible to find nanosystems based on $\mathrm{Ag}$ nanoparticles (AgNPs) and $\mathrm{Ag}^{+}$ cations with similar performance, although of course the overall dosage of silver when AgNPs are employed is significantly higher. Regarding the effect of silver onto bacteria there could be highlighted the following aspects: (1) gram-negative bacteria are more susceptible due to a narrower bacterial wall that facilitates $\mathrm{Ag}^{+}$ permeation. $^{82}$ (2) A fully functional biofilm protects bacteria from both silver ions and nanoparticles by reducing their mobility throughout its architecture, specially in the case of larger nanoparticles. And (3), highly charged particles would experience diffusion issues due to strong electrostatic interactions between particles and biofilms. ${ }^{83}$ For this reason, best antibacterial effects are typically obtained with nanosystems on which cationic silver is released (Figure 3).

On one of the first contributions to the topic, Zink and coworkers pioneered the use of Ag-Silica nanohybrids for the treatment of infections. ${ }^{84}$ On this work the authors prepared Ag@MSNs which was further loaded with a PEI polymer, proving an antibacterial effect in two cell lines E. coli and B. anthracis. However, the reported antibiotic effect is not fully clear; as it could be caused either by a pH-driven detachment of the coating PEI, by a release of $\mathrm{Ag}^{+}$throughout the mesopores or by combination of both. Nevertheless, their results set the basis for future experiments in both silver delivery with nanometric silica devices and combination therapies. (Table 3).

Despite the advance reported by Zink and coworkers, sequent works were focused on designing nanodevices

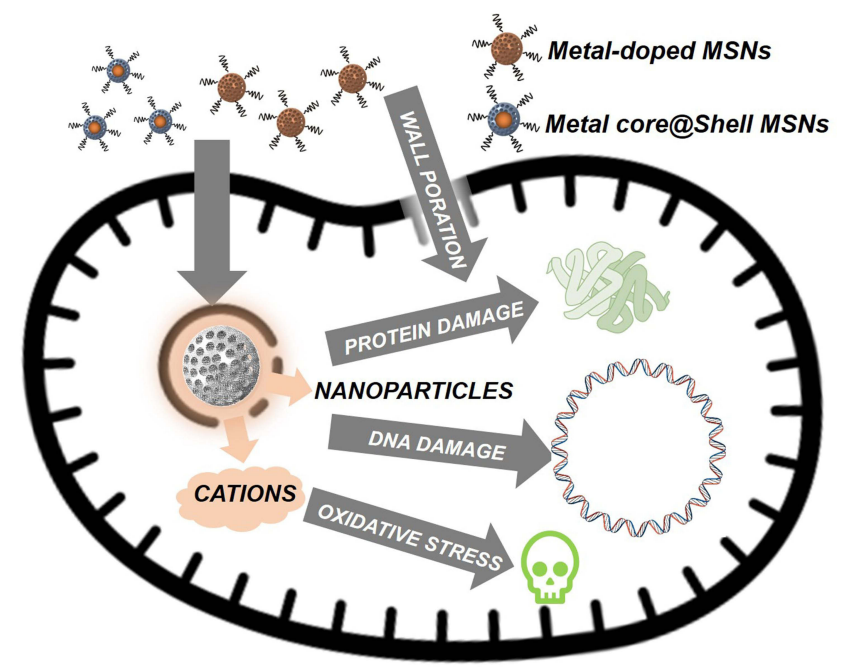

Figure 3 Different known antibiotic effects triggered by metals colloids and cations. These effects are of particular importance with silver, although known for $\mathrm{Cu}, \mathrm{Zn}$, and Fe among other metals.

onto which the antibacterial AgNPs would be exposed instead of encapsulated into silica in order to accelerate the antibacterial effect. Along this line Tian et al reported the use of a ethylenediamine moiety onto silica's surface to coordinate $\mathrm{Ag}^{+}$ions onto which grow AgNPs. ${ }^{85}$ Their nanosystem was able to inhibit both a gram-negative (E. coli) and gram-positive (S. aureus) bacteria in liquid cultures; although this device was much more effective when tested against the gram-negative E. coli bacteria $\left(\mathrm{OD}_{600}\right.$ dropped to zero at $80 \mu \mathrm{g} / \mathrm{mL}$ MSN@Ag) than against $S$. aureus $\left(\mathrm{OD}_{600}=0\right.$ at $320 \mu \mathrm{g} / \mathrm{mL}$ MSN@Ag). Regarding the effect onto HUVEC eukaryotic cells, the authors found a 10 -fold increased biocompatibility of carried silver when compared to free silver cations (added as $\mathrm{AgNO}_{3}$ ).

The previous results pushed other research groups to investigate the potential of MSN@Ag hybrids as nanoantibiotics; although with additional mechanisms to control AgNPs release in order to have more sustained effects. Along this line Wan et al employed sulfonate-modified MSNs onto which coordinate $\mathrm{Ag}^{+}$to further prepare monodisperse AgNPs by in-situ reduction. ${ }^{86}$ With this approach the authors prepared a model in which the resulting AgNPs had a relative small size and a fantastic dispersion throughout the silica, allowing to reach complete destruction of $E$. coli colonies at a concentration near $50 \mu \mathrm{g} / \mathrm{mL}$ and $S$. aureus at about $150 \mu \mathrm{g} / \mathrm{mL}$. Following a parallel strategy, Song et al employed sulfonatemodified SBA-15 MSNs to prepare their MSN@AgNPs; although in this case with an additional coating of 
Table 3 Silica-based Porous Nanosystems with Antibacterial Effect Based on Metal Delivery

\begin{tabular}{|c|c|c|c|c|c|c|c|c|}
\hline $\begin{array}{l}\text { Silica } \\
\text { Nanocarrier }\end{array}$ & $\begin{array}{c}\text { Antibacterial } \\
\text { Component }\end{array}$ & $\begin{array}{c}\text { Primary } \\
\text { Action } \\
\text { Mechanism }\end{array}$ & $\begin{array}{l}\text { Antibiotic } \\
\text { Species } \\
\text { Loading }\end{array}$ & $\begin{array}{c}\text { Antibiotic } \\
\text { Species Release } \\
\text { Mechanism }\end{array}$ & $\begin{array}{l}\text { In vitro } \\
\text { Evaluation } \\
\text { (bacteria) }\end{array}$ & $\begin{array}{c}\text { In vitro } \\
\text { Evaluation } \\
\text { (Eukaryotic } \\
\text { Cells) }\end{array}$ & in vivo & Ref. \\
\hline \multicolumn{9}{|c|}{ Metal-modified Silica Nanosystems } \\
\hline Ag@MSN & $\begin{array}{l}\text { Silver } \\
\text { PEI }\end{array}$ & $\begin{array}{c}\text { Silver } \\
\text { sensitization }\end{array}$ & PEI & $\begin{array}{l}\mathrm{pH} \text {-driven } \\
\text { detachment }\end{array}$ & $\begin{array}{l}\text { E. coli } \\
\text { B. anthracis }\end{array}$ & None & None & 84 \\
\hline $\begin{array}{l}\text { MCM-4I } \\
\text { MSNs }\end{array}$ & Silver & $\begin{array}{c}\text { Silver } \\
\text { sensitization }\end{array}$ & $\begin{array}{l}\text { Ethylenediamine- } \\
\text { AgNPs complex }\end{array}$ & $\mathrm{Ag}$ decomplexation & $\begin{array}{l}\text { E. coli } \\
\text { S. aureus }\end{array}$ & HUVECs & None & 85 \\
\hline $\begin{array}{l}\text { MCM-4I } \\
\text { MSNs }\end{array}$ & Silver & $\begin{array}{c}\text { Silver } \\
\text { sensitization }\end{array}$ & $\begin{array}{l}\text { Sulfonate-AgNPs } \\
\text { complex }\end{array}$ & $\mathrm{Ag}$ decomplexation & $\begin{array}{c}\text { E. coli } \\
\text { S. aureus }\end{array}$ & None & None & 86 \\
\hline SBA-I5 MSNs & Silver & $\begin{array}{c}\text { Silver } \\
\text { sensitization }\end{array}$ & $\begin{array}{l}\text { Sulfonate-AgNPs } \\
\text { complex }\end{array}$ & $\mathrm{Ag}$ decomplexation & $\begin{array}{l}\text { E. coli } \\
\text { S. aureus } \\
\text { A. fumigatus }\end{array}$ & None & None & 87 \\
\hline $\begin{array}{l}\text { MCM-4I } \\
\text { MSNs }\end{array}$ & Silver & $\begin{array}{c}\text { Silver } \\
\text { sensitization }\end{array}$ & $\begin{array}{c}\text { Ethylenediamine- } \\
\text { AgNPs complex } \\
\text { vs } \\
\text { Core-shell } \\
\text { structure }\end{array}$ & $\begin{array}{c}\mathrm{Ag} \text { decomplexation } \\
\text { vs } \\
\mathrm{Ag} \text { dissolution }\end{array}$ & M. tuberculosis & None & None & 88 \\
\hline $\begin{array}{l}\text { Ag@MSN@ } \\
\text { Alginate }\end{array}$ & Silver & $\begin{array}{c}\text { Silver } \\
\text { sensitization }\end{array}$ & $\begin{array}{l}\text { Core-shell } \\
\text { loading of } \\
\text { AgNPs }\end{array}$ & $\begin{array}{l}\text { Nanoparticle } \\
\text { dissolution }\end{array}$ & $\begin{array}{l}\text { S. aureus } \\
\text { S. epidermidis } \\
\text { P. aeruginosa } \\
\text { C. albicans }\end{array}$ & $\begin{array}{c}\text { HuDe } \\
\text { NCTC2544 }\end{array}$ & None & 89 \\
\hline $\begin{array}{l}\text { MCM-4I } \\
\text { MSNs }\end{array}$ & $\begin{array}{c}\mathrm{Zn}, \mathrm{Cu}, \mathrm{Fe} \text {, or } \\
\mathrm{Cr}\end{array}$ & $\begin{array}{c}\text { Metal } \\
\text { sensitization }\end{array}$ & Calcination & $\begin{array}{c}\text { Nanoparticle } \\
\text { dissolution }\end{array}$ & $\begin{array}{c}\text { S. aureus } \\
\text { B. subtilis } \\
\text { P. aeruginosa } \\
\text { E. coli }\end{array}$ & None & None & 93 \\
\hline MSNs & $\begin{array}{l}\text { Silver and/or } \\
\text { Zinc }\end{array}$ & $\begin{array}{c}\text { Metal } \\
\text { sensitization }\end{array}$ & $\begin{array}{l}\mathrm{Ag}, \mathrm{Zn} \text {, and } \mathrm{Ag} / \\
\mathrm{Zn} \text { doping }\end{array}$ & $\begin{array}{l}\text { Nanoparticle } \\
\text { dissolution }\end{array}$ & E. faecalis & МС3ТЗ-EI & None & 94 \\
\hline
\end{tabular}

Abbreviations: AgNPs, silver nanoparticles; PEI, polyethyleneimine; eukaryotic cell lines: HuDe, human dermis fibroblast; HUVEC, human umbilical vein endothelial cells; NCTC2544, human skin keratinocytes; Prokaryotic cell lines: A. fumigatus, Aspergillus fumigatus; B. anthracis, Bacillus anthracis; B. subtilis, Bacillus subtilis; C. albicans, Candida albicans; E. coli, Escherichia coli; M. tuberculosis, Mycobacterium tuberculosis; S. aureus, Staphylococcus aureus.

polydopamine which embedded the MSN@AgNPs hybrids. ${ }^{87}$ The resulting system proved to be effective against $E$. coli, $S$. aureus and A. fumigatus colonies at a concentration of $4 \mathrm{mg}$ of the nanocomposite per petri dish; although much faster on the case of gram-negative E. coli.

Our group has been also interested on the use of AgSilica composites in the fight of infections. On a very recent contribution Montalvo-Quirós et al studied the different performance of both approaches reviewed so far: a core-shell structure in which a big AgNP is coated by a silica layer and model that grows AgNPs within the mesopores. ${ }^{88}$ Both structures were prepared successfully and tested against $M$. tuberculosis. It was found that the approach onto AgNPs were grown at the mesopores had a higher antibiotic effect that could be assumed to be consequence of an increased dissolution rate of AgNPs together with a more intimate contact between particles and mycobacteria.

The previous examples, focused on measuring the antibacterial activity, show the great potential of these Ag$\mathrm{SiO}_{2}$ systems. However, it is also interesting to know how these nanoantibiotics perform in clinical applications. Along this line Ambrogi et al reported the use of Ag@MSNs embedded in alginate to prepare composite films for wound treatments. ${ }^{89}$ Here in, the topic 
administration of silver-silica composites permits to have more laxity on particles' size and morphology, which will reduce the final cost. The system proposed by these authors showed effective antibiotic effects on typical bacterial lines and onto the $C$. albicans yeast. In addition, due to the alginate and silica layers the silver toxicity was diminished to acceptable levels as showed on cellular assays onto human keratinocyte and fibroblast cell lines.

Table 4 Silica-based Nanosystems Suitable for Combined Antibacterial Therapies

\begin{tabular}{|c|c|c|c|c|c|c|c|c|}
\hline $\begin{array}{l}\text { Silica } \\
\text { Nanocarrier }\end{array}$ & $\begin{array}{l}\text { Antibacterial } \\
\text { Component }\end{array}$ & $\begin{array}{c}\text { Primary } \\
\text { Action } \\
\text { Mechanism }\end{array}$ & $\begin{array}{l}\text { Antibiotic } \\
\text { Species } \\
\text { Loading }\end{array}$ & $\begin{array}{c}\text { Antibiotic } \\
\text { Species Release } \\
\text { Mechanism }\end{array}$ & $\begin{array}{c}\text { In vitro } \\
\text { Evaluation } \\
\text { (bacteria) }\end{array}$ & $\begin{array}{c}\text { In vitro } \\
\text { Evaluation } \\
\text { (Eukaryotic } \\
\text { Cells) }\end{array}$ & in vivo & Ref \\
\hline \multicolumn{9}{|c|}{ Combined Antibiotic Therapies } \\
\hline $\mathrm{SiO}_{2} \mathrm{NPs}$ & $\begin{array}{l}\text { Gentamicin } \\
\text { Rifamycin }\end{array}$ & $\begin{array}{l}\text { Antibiotic } \\
\text { co-delivery }\end{array}$ & $\begin{array}{l}\text { Layer by } \\
\text { layer loading }\end{array}$ & $\begin{array}{c}\text { Nanoparticle } \\
\text { dissolution }\end{array}$ & $\begin{array}{c}\text { S. aureus } \\
\text { P. aeruginosa }\end{array}$ & None & None & 99 \\
\hline SBA-I5 MSNs & $\begin{array}{l}\text { Vancomycin } \\
\text { Rifampin }\end{array}$ & $\begin{array}{l}\text { Antibiotic } \\
\text { co-delivery }\end{array}$ & Pore loading & Pore diffusion & $\begin{array}{l}\text { S. aureus } \\
\text { S. Epidermis }\end{array}$ & None & None & II \\
\hline $\begin{array}{l}\text { MCM-4I } \\
\text { MSNs }\end{array}$ & $\begin{array}{l}\text { Vancomycin } \\
\text { Polymyxin B }\end{array}$ & $\begin{array}{l}\text { Antibiotic } \\
\text { co-delivery }\end{array}$ & Pore loading & Pore diffusion & $\begin{array}{c}\text { E. coli } \\
\text { S. aureus } \\
\text { P. aeruginosa }\end{array}$ & None & None & 100 \\
\hline $\begin{array}{l}\text { MCM-4I } \\
\text { MSNs }\end{array}$ & $\begin{array}{l}\text { Silver-Indole } \\
\text {-3-acetic acid } \\
\text { complex }\end{array}$ & $\begin{array}{c}\text { Metal } \\
\text { sensitization and } \\
\text { prodrug delivery }\end{array}$ & Pore loading & Pore diffusion & $\begin{array}{l}\text { E. coli } \\
\text { B. subtilis } \\
\text { S. aureus } \\
\text { S. epidermis. }\end{array}$ & None & None & 101 \\
\hline $\begin{array}{l}\text { LP-MSNs } \\
@ M M S N s\end{array}$ & $\begin{array}{l}\text { Melittin } \\
\text { Ofloxacin }\end{array}$ & $\begin{array}{l}\text { Antibiotic drug- } \\
\text { peptide co- } \\
\text { delivery }\end{array}$ & Pore loading & $\begin{array}{l}\text { Magnetic-triggered } \\
\text { supramolecular } \\
\text { disassembly }\end{array}$ & P. aeruginosa & $\begin{array}{l}\text { NIH3T3 } \\
\text { HEK293T }\end{array}$ & None & 103 \\
\hline $\begin{array}{l}\text { MMSNs- } \\
\text { EMPO }\end{array}$ & $\begin{array}{l}\text { Gentamicin } \\
\text { Curcumin }\end{array}$ & $\begin{array}{l}\text { Antibiotic } \\
\text { co-delivery }\end{array}$ & Pore loading & Pore diffusion & $\begin{array}{c}\text { E. coli } \\
\text { S. aureus }\end{array}$ & MCF-7 & None & 104 \\
\hline Ag@MSN & Levofloxacin & $\begin{array}{c}\text { Metal } \\
\text { sensitization } \\
\text { Antibiotic } \\
\text { delivery }\end{array}$ & Pore loading & $\begin{array}{l}\text { AgNP dissolution - } \\
\text { Loaded drug } \\
\text { diffusion }\end{array}$ & $\begin{array}{c}\text { E. coli } \\
\text { K. pneumoniae }\end{array}$ & None & Mice & 105 \\
\hline $\begin{array}{l}\text { Janus AgNP- } \\
\text { MSN }\end{array}$ & CTAB & $\begin{array}{c}\text { Metal } \\
\text { sensitization } \\
\text { Membrane lysis }\end{array}$ & $\begin{array}{l}\text { Core-shell } \\
\text { loading of } \\
\text { AgNPs } \\
\text { Pore loading }\end{array}$ & $\begin{array}{l}\text { AgNP dissolution - } \\
\text { Loaded drug } \\
\text { diffusion }\end{array}$ & $\begin{array}{c}\text { E. coli } \\
\text { S. aureus }\end{array}$ & None & None & 106 \\
\hline LP-MSNs & Silver & $\begin{array}{c}\text { Silver } \\
\text { sensitization } \\
\text { DNA cleavage }\end{array}$ & $\begin{array}{l}\text { Silver doping } \\
\text { Enzyme- } \\
\text { loading }\end{array}$ & $\begin{array}{l}\mathrm{Ag}^{+} \text {release - } \\
\text { Enzyme release }\end{array}$ & $\begin{array}{c}\text { E. coli } \\
\text { S. mutans }\end{array}$ & None & None & 107 \\
\hline SBA-I 5 MSNs & $\begin{array}{c}\text { Silver } \\
\text { Curcumin }\end{array}$ & $\begin{array}{c}\text { Silver } \\
\text { sensitization }\end{array}$ & $\begin{array}{c}\text { Silver } \\
\text { doping - } \\
\text { Drug- } \\
\text { loading }\end{array}$ & $\begin{array}{l}\mathrm{Ag}^{+} \text {release - } \\
\text { Drug release }\end{array}$ & $\begin{array}{l}\text { E. coli } \\
\text { S. aureus }\end{array}$ & $\begin{array}{c}\text { HeLa } \\
\text { HEK-293T }\end{array}$ & None & 108 \\
\hline
\end{tabular}

Abbreviations: EMPO, ethane bridged periodic mesoporous organosilica; HMSNs, hollow MSNs; PEl, polyethyleneimine; MMSNs, core-shell magnetic MSNs; LP-MSNs, large-pore MSNs. Eukaryotic cell lines, HEK293T, human embryonic kidney; HeLa, human cervix adenocarcinoma; NIH3T3, murine embryonic fibroblasts; MCF-7, human breast ductal carcinoma. Prokaryotic cell lines, B. subtilis, Bacillus subtilis; E. coli, Escherichia coli; K. pneumoniae, Klebsiella pneumoniae; M. tuberculosis, Mycobacterium tuberculosis; P. aeruginosa, Pseudomonas aeruginosa; P. gingivalis, Porphyromonas gingivalis; S. aureus, Staphylococcus aureus; S. epidermis, Staphylococcus epidermis; S. mutans, Staphylococcus mutans. 


\section{Antibacterial Effects of Metal-doped Mesoporous Silica Nanocomposites}

Apart from silver, many other metals are also known to show antibacterial properties. ${ }^{90-92}$ Although this effect is significantly lower than that provided by Ag, their lower costs and rapid availability also makes them interesting candidates for the development of silica-based nanoantibiotics. Along this line, Hachemaoui et al studied the antibacterial effect achieved of MCM-41 MSNs doped with several cations. ${ }^{93}$ Their results showed that between the metals tested there were no significant differences regarding antibacterial effects, although a clear bias could be appreciated toward non-calcined materials, which in all cases improved the performance of calcined ones according to the Kirby-Bauer tests reported. From these data, it could be assumed that the main antibiotic mechanism is metal diffusion, which is known to be less efficient into calcined materials. One other interesting contribution, Leng et al compared the antibiotic effect of silver- and zinc-doped mesoporous calcium silicates for dental fillings. ${ }^{94}$ Their results show that both cations and their combinations exert a low biocidal effect against E. faecalis and murine preosteoblasts, but a significant reduction of the number of colonies formed and thus on the biofilm formation, a highly valuable feature to prevent dental implant failure. Moreover, the enhanced activity of the $\mathrm{Zn}-\mathrm{Ag}$ combination is also interesting because apart from reducing costs it also improves the overall performance, bringing out the potential of single-device antibiotic combinations.

One of the last metals to arrive for antibacterial treatment is iron, either in a colloidal form ${ }^{95,96}$ or as doping element. The antibacterial possibilities of iron are huge as they can perform such effects by either thermal destruction of bacteria, ${ }^{97}$ production of toxic reactive oxygen species (ROS) throughout Fenton-like reactions ${ }^{17,92}$ or upon a membrane depolarization only in the case of iron oxide particles (IONs). ${ }^{98}$ Despite the number of IONs@MSN nanosystems reported with promising applications on anticancer therapy, we did not find any silica-containing nanodevice applied against bacterial infection. Perhaps in the near future the outstanding performance of IONs as ferroptosis inductors and thermal sensitizer in combination with mesoporous silica would produce a new family of antiinfectives.

\section{Combined Antibiotic Therapies}

Combination therapy has become a powerful tool for nanomedicine, as it allows us to exert several effects with a single device, as reviewed by us focused on cancer therapy; ${ }^{17,18}$ and similarly, bacterial infections could be treated with more than one biocidal. Among all the possibilities we will focus on the main strategies developed so far in order to shed some light onto a very complex field of research (Table 4).

\section{Antibiotic Codelivery}

The first and easiest way to combine antibiotic effects is simultaneous loading and delivery of drugs. However, to implement this strategy, a gating component would be needed at the pore in order to prevent undesired leakages and to enable bacterial-triggered drug release. However, reported examples seem to be on a previous development stage as they do not include this feature. In the example by Mebert et $\mathrm{al}^{99}$ the loading was achieved by using a multilayered construction of silica nanoparticles with a step-by-step loading of gentamicin and rifamycin. In contrast, Aguilar-Colomer et $\mathrm{al}^{10}$ and Gounani et $\mathrm{al}^{100}$ employed the convenient porous structure of MSNs (either SBA-15 or MCM-41) to co-load two antibiotic species. In general, the results show good bacterial remission, although due to the diffusion-driven release, these examples may not be suitable for intracellular infections and parenteral administration. Another interesting example on the topic was reported by Kuthati et al who employed Ag -indole-3-acetic acid hydrazides (Ag-IAA) complexes to kill bacteria. ${ }^{101}$ Herein, the $\mathrm{Ag}^{+}$cations and the indoleacetic acid prodrug could be simultaneously delivered due to the $\mathrm{pH}$-sensitive hydrazide bonds that connected AgIAA to mesopores. This nanosystem, tested against several bacterial lines showed good antibiotic effect, although even in the absence of a specific reductor for the IAA a maximal effect could not be obtained. ${ }^{102}$

Regarding other possible combinations, we want to highlight the work by $\mathrm{Yu}$ et al who reported the codelivery of the antimicrobial peptide melittin with ofloxacin. ${ }^{103}$ For this device example the authors employed a well-developed technology onto which large pore MSNs containing the peptide were coated with a cucurbiturilmodified PEI onto which assemble adamantane-modified magnetic MSNs to close the pores. The system, which was disassembled under alternating magnetic fields, proved to have a good antibacterial effect against $P$. aeruginosa and 
good biocompatibility against HEK293 and NIT3T3 cell lines. Another interesting approach to co-deliver substances is the use of Janus nanoparticles, in this case with different adsorption domains. Along this line, Cheng et al reported the use of core-shell magnetic MSNs (MMSNs) grafted to ethane-bridged mesoporous periodic organosilica (EMPO) with different loading properties. Herein the authors profited from two different loading rates between the two employed silica materials: gentamicin was preferentially loaded between the silica while the curcumin within the organosilica. ${ }^{104}$ The resulting system proved to have a good biocidal performance as was able to destroy bacteria and cancerous cells alike, demonstrating the potential of drug combinations.

\section{Silver-containing Silica Nanoparticles for Antibiotic Delivery}

Silver-containing silica nanoparticles reviewed above have also been successfully employed for combination treatments. In one of the first examples reported, Wang et al reported the use of core-shell AgNPs@MSNs loaded with levofloxacin to treat peritoneal infection on mice. ${ }^{105}$ Herein the authors studied the $\mathrm{Ag}$ dissolution kinetics proving that the internal core was able to dissolve slowly, releasing silver ions able to cause bacterial damage. In this article, two bacterial lines were successfully destroyed with this combination and when tested in vivo this system was capable of promoting survival of mice with acute peritonitis.

Another possible strategy to combine AgNPs and mesoporous silica was reported by Chang et al, who reported the use of Janus-Silver-MSN nanobullets in which the silica mesopores were filled with the forming template CTAB. ${ }^{106}$ In this case, the authors prepared a very simplified model into which the AgNP was exposed and permitted a facile $\mathrm{Ag}^{+}$release and the porous silica remained unextracted and was able to release membranelytic cetyltrimethylammonium cations $\left(\mathrm{CTA}^{+}\right)$. Moreover, the authors also claimed that the silica surface was able to stabilize $\mathrm{Ag}^{+}$ions and boost the antibacterial activity. This system as is, is a very interesting a proof of concept; although in its current configuration, lacking from protective coatings able to prevent $\mathrm{CTA}^{+}$release and immunestealthening, has very few possibilities to be applied in vivo.

Regarding silver-doped silica particles, two interesting approaches on the recent literature were found. For instance, Tasia et al reported the use of Ag-doped, large pore MSNs suitable to load and deliver the DNase I enzyme ${ }^{107}$ with great effect on $E$. coli and $S$. mutans biofilms due to the combination of $\mathrm{Ag}^{+}$sensitization and enzymatic degradation of the intracellular DNA; although the lack of a protective layer may lead to a very limited shelf-life of the enzyme. This limitation could be overcome by using the system reported by Song et al, who designed polydopamine-coated Ag-doped SBA-15 MSNs to deliver curcumin to both bacteria and cancerous cells. ${ }^{108}$ In this case, despite the potential of their nanosystem the chosen drug did not produce a significant anticancer effect. However, an opposite effect was observed onto prokaryotic cells, which permitted complete destruction of E. coli colonies at $2 \mathrm{mg}$ per petri dish and a significant colony formation (up to $36 \mathrm{~h}$ ) against S. aureus.

\section{Conclusion}

This review has focused on the use of silica nanoparticles and related silica-based hybrids as promising nanotechnological approaches for the control and treatment of infectious processes. Herein, apart from visiting the most recent advances in drug delivery published so far, we have highlighted the most promising applications of mesoporous silica on preventive nanomedicine.

Regarding drug delivery, it is widely accepted that the unique porous structure of mesoporous silica is a highly desired feature for the development of newgeneration pharmacological formulations; ranging from controlled delivery to the development of unique multidrug delivery systems. During the last decade those aspects have been widely studied on the development of anticancer nanosystems, although unfortunately, the desired effective leap toward clinical research has not yet been taken. For this reason, current research on MSNs seems to have shifted from anticancer nanomedicine to anti-infective processes that avoid parenteral drug delivery. For instance, it has been possible to design effective formulations based on porous silica as components for cements and dental filling materials or even topical formulations able to keep bacterial infection under control with common antibiotics. We believe that antibiotic drug delivery will bloom during the following years; as MSNs are one of the very few platforms that permit implementation of (1) multidrug delivery, (2) dosage of antibiotic peptides and (3) the exploitation of extracts and oils as mild antibiotics. Perhaps this 
evolution may avoid the intravenous injection but may have a future in implants and drug patch technologies.

Apart from the promising advances on drug delivery, MSNs also have demonstrated an outstanding robustness against chemical modifications. This permits us to create polyionic compounds with antibacterial and antibiofilm properties. Again, it is clear that clinical assays are still to be made, but it is also important to remark that very few of those nanosystems are really in an anti-infection race. Indeed, even less of these materials would allow us to implement the current state-of-the-art in nanopharmaceutical research on future antibacterial applications; silica being one of the best candidates for such purpose. To conclude, it is also important to remark that silica allows, like no other material, the development of hybrid nanosystem able to combine therapeutic features. For instance, the combination with colloidal silver has permitted us to develop interesting candidates for synergic therapies.

In summary, we believe that the topics reviewed herein highlight the potential of MSNs and related materials for the development of effective nanoantibiotics. Furthermore, in the light of the reported examples, we truly believe that silica is still to pioneer a revolution in the development of new generation antibacterial nanotherapeutics in disciplines like dentistry, wound care, and regenerative tissue engineering.

\section{Acknowledgment}

The authors want to acknowledge financial support from European Research Council ERC-2015- AdG-694160 for financial support.

\section{Disclosure}

The authors report no conflicts of interest in this work.

\section{References}

1. Penesyan A, Gillings M, Paulsen PI. Antibiotic discovery: combatting bacterial resistance in cells and in biofilm communities. Molecules. 2015;20(4):5286-5298. doi:10.3390/molecules20045286

2. Lemire JA, Harrison JJ, Turner RJ. Antimicrobial activity of metals: mechanisms, molecular targets and applications. Nat Rev Microbiol. 2013;11(6):371-384. doi:10.1038/nrmicro3028

3. Jolivet-Gougeon A, Bonnaure-Mallet M. Biofilms as a mechanism of bacterial resistance. Drug Discov Today Technol. 2014;11:49-56. doi:10.1016/j.ddtec.2014.02.003

4. Duval RE, Grare M, Demoré B. Fight against antimicrobial resistance: we always need new antibacterials but for right bacteria. Molecules. 2019;24 (17):3152. doi:10.3390/molecules24173152

5. Makabenta JMV, Nabawy A, Li C-H, Schmidt-Malan S, Patel R, Rotello VM. Nanomaterial-based therapeutics for antibiotic-resistant bacterial infections. Nat Rev Microbiol. 2021;19(1):23-36. doi:10.1038/s41579-020-0420-1
6. Wang L, Hu C, Shao L. The-antimicrobial-activity-of-nanoparticles -present-situati. Int J Nanomedicine. 2017;12:1227-1249.

7. Vallet-Regí M, Lozano D, González B, Izquierdo-Barba I. Biomaterials against Bone Infection. Adv Healthc Mater. 2020;9 (13):2000310. doi:10.1002/adhm.202000310

8. Aguilera-Correa JJ, Esteban J, Vallet-Regí M. Inorganic and polymeric nanoparticles for human viral and bacterial infections prevention and treatment. Nanomaterials. 2021;11(1):1-26. doi:10.3390/nano11010137

9. Wang Y, Yang Y, Shi Y, Song H, Yu C. Antibiotic-free antibacterial strategies enabled by nanomaterials: progress and perspectives. Adv Mater. 2020;32(18):1-21. doi:10.1002/ adma.201904106

10. Martínez-Carmona M, Gun'ko YK, Vallet-Regí M. Mesoporous silica materials as drug delivery: "the nightmare" of bacterial infection. Pharmaceutics. 2018;10(4):1-29. doi:10.3390/ pharmaceutics 10040279

11. Bernardos A, Piacenza E, Sancenón F, et al. Mesoporous silica-based materials with bactericidal properties. Small. 2019;15(24):1-34. doi:10.1002/smll.201900669

12. Colilla M, Vallet-Regí M. Targeted stimuli-responsive mesoporous silica nanoparticles for bacterial infection treatment. Int $J \mathrm{Mol}$ Sci. 2020;21:8605. doi:10.3390/ijms21228605

13. Pham TN, Loupias P, Dassonville-Klimpt A, Sonnet P. Drug delivery systems designed to overcome antimicrobial resistance. Med Res Rev. 2019;39(6):2343-2396. doi:10.1002/ med. 21588

14. Selvarajan V, Obuobi S, Ee PLR. Silica nanoparticles-a versatile tool for the treatment of bacterial infections. Front Chem. 2020;8: (July):1-16. doi:10.3389/fchem.2020.00602

15. Vallet-Regi M, Rámila A, Del Real RP, Pérez-Pariente J, New A. Property of MCM-41: drug delivery system. Chem Mater. 2001;13(2):308-311. doi:10.1021/cm0011559

16. Vallet-Regí M, Balas F, Arcos D. Mesoporous materials for drug delivery. Angew Chem Int Ed Engl. 2007;46(40):7548-7558. doi:10.1002/anie. 200604488

17. Castillo RR, Vallet-Regí M. Emerging strategies in anticancer combination therapy employing silica-based nanosystems. Biotechnol J. 2021;16(3):1900438. doi:10.1002/biot.201900438

18. Castillo RR, Colilla M, Vallet-Regí M. Advances in mesoporous silica-based nanocarriers for co-delivery and combination therapy against cancer. Expert Opin Drug Deliv. 2017;14(2):229-243. doi:10.1080/17425247.2016.1211637

19. Castillo RR, Lozano D, González B, Manzano M, IzquierdoBarba I, Vallet-Regí M. Advances in mesoporous silica nanoparticles for targeted stimuli-responsive drug delivery: an update. Expert Opin Drug Deliv. 2019;16(4):415-439. doi:10.1080/ 17425247.2019.1598375

20. Castillo RR, de la Torre L, García-Ochoa F, Ladero M, ValletRegí M. Production of MCM-41 nanoparticles with control of particle size and structural properties: optimizing operational conditions during scale-up. Int J Mol Sci. 2020;21(21):7899. doi:10.3390/ijms21217899

21. Castillo RR, Lozano D, Vallet-Regí M. Mesoporous silica nanoparticles as carriers for therapeutic biomolecules. Pharmaceutics. 2020;12(5):432. doi:10.3390/pharmaceutics12050432

22. Rodrigues CF, Alves CG, Lima-Sousa R, Moreira AF, de Melo-diogo D, Correia IJ. Inorganic-based drug delivery systems for cancer therapy. In: Advances and Avenues in the Development of Novel Carriers for Bioactives and Biological Agents. Elsevier; 2020:283-316. doi:10.1016/B978-0-12819666-3.00010-9

23. Jiao M, Zhang P, Meng J, et al. Recent advancements in biocompatible inorganic nanoparticles towards biomedical applications. Biomater Sci. 2018;6(4):726-745. doi:10.1039/C7BM01020F 
24. Paris JL, Colilla M, Izquierdo-Barba I, Manzano M, Vallet-Regí M. Tuning mesoporous silica dissolution in physiological environments: a review. J Mater Sci. 2017;52(15):8761-8771. doi:10.1007/s10853-017-0787-1

25. Tang F, Li L, Chen D. Mesoporous Silica nanoparticles: synthesis, biocompatibility and drug delivery. Adv Mater. 2012;24 (12):1504-1534. doi:10.1002/adma.201104763

26. Castillo RR, Vallet-Regi M. Functional Mesoporous Silica nanocomposites: biomedical applications and biosafety. Int J Mol Sci. 2019;20(4):929. doi:10.3390/ijms20040929

27. Croissant JG, Fatieiev Y, Almalik A, Khashab NM. Mesoporous silica and organosilica nanoparticles: physical chemistry, biosafety, delivery strategies, and biomedical applications. Adv Healthc Mater. 2018;7(4):1700831. doi:10.1002/adhm.201700831

28. Ipe DS, Kumar PTS, Love RM, Hamlet SM. Silver nanoparticles at biocompatible dosage synergistically increases bacterial susceptibility to antibiotics. Front Microbiol. 2020;11. doi:10.3389/ fmicb.2020.01074.

29. Qi G, Li L, Yu F, Wang H. Vancomycin-modified mesoporous silica nanoparticles for selective recognition and killing of pathogenic Gram-positive bacteria over macrophage-like cells. ACS Appl Mater Interfaces. 2013;5(21):10874-10881. doi:10.1021/ am403940d

30. Agnihotri S, Pathak R, Jha D, et al. Synthesis and antimicrobial activity of aminoglycoside-conjugated silica nanoparticles against clinical and resistant bacteria. New J Chem. 2015;39 (9):6746-6755. doi:10.1039/C5NJ00007F

31. Dong A, Xue M, Lan S, et al. Bactericidal evaluation of N-halamine-functionalized silica nanoparticles based on barbituric acid. Colloids Surf B Biointerfaces. 2014;113:450-457. doi:10.1016/j.colsurfb.2013.09.048

32. Li C, Hou J, Huang Z, et al. Assessment of 2,2,6,6-tetramethyl4-piperidinol-based amine N-halamine-labeled silica nanoparticles as potent antibiotics for deactivating bacteria. Colloids Surf $B \quad$ Biointerfaces. 2015;126:106-114. doi:10.1016/j. colsurfb.2014.11.051

33. Capeletti LB, De Oliveira LF, Gonçalves KDA, et al. Tailored silica-antibiotic nanoparticles: overcoming bacterial resistance with low cytotoxicity. Langmuir. 2014;30(25):7456-7464. doi:10.1021/la4046435

34. Nor YA, Niu Y, Karmakar S, et al. Shaping nanoparticles with hydrophilic compositions and hydrophobic properties as nanocarriers for antibiotic delivery. ACS Cent Sci. 2015;1(6):328-334. doi:10.1021/acscentsci.5b00199

35. Li X, Wong CH, Ng TW, Zhang CF, Leung KCF, Jin L. The spherical nanoparticle-encapsulated chlorhexidine enhances anti-biofilm efficiency through an effective releasing mode and close microbial interactions. Int $J$ Nanomedicine. 2016;11:2471-2480. doi:10.2147/IJN.S105681

36. Nairi V, Medda L, Monduzzi M, Salis A. Adsorption and release of ampicillin antibiotic from ordered mesoporous silica. $J$ Colloid Interface Sci. 2017;497:217-225. doi:10.1016/j.jcis.2017.03.021

37. Deaconu M, Nicu I, Tincu R, et al. Tailored doxycycline delivery from MCM-41-type silica carriers. Chem Pap. 2018;72 (8):1869-1880. doi:10.1007/s11696-018-0457-z

38. Brezoiu A-M, Deaconu M, Nicu I, et al. Heteroatom modified MCM-41-silica carriers for Lomefloxacin delivery systems. Microporous Mesoporous Mater. 2019;275:214-222. doi:10.1016/j.micromeso.2018.08.031

39. Gounani Z, Asadollahi MA, Meyer RL, Arpanaei A. Loading of polymyxin $\mathrm{B}$ onto anionic mesoporous silica nanoparticles retains antibacterial activity and enhances biocompatibility. Int $J$ Pharm. 2018;537(1-2):148-161. doi:10.1016/j. ijpharm.2017.12.039
40. He Y, Zhang Y, Sun M, et al. One-pot synthesis of chlorhexidine-templated biodegradable mesoporous organosilica nanoantiseptics. Colloids Surf B Biointerfaces. 2020;187 (July2019):110653. doi:10.1016/j.colsurfb.2019.110653

41. Subramaniam S, Thomas N, Gustafsson H, Jambhrunkar M, Kidd SP, Prestidge CA. Rifampicin-loaded mesoporous silica nanoparticles for the treatment of intracellular infections. Antibiotics. 2019;8(2):5-7. doi:10.3390/antibiotics8020039

42. Joyce P, Ulmefors H, Maghrebi S, et al. Enhancing the cellular uptake and antibacterial activity of rifampicin through encapsulation in mesoporous silica nanoparticles. Nanomaterials. 2020;10 (4):815. doi:10.3390/nano10040815

43. Thakur A, Mikkelsen H, Jungersen G. Intracellular pathogens: host immunity and microbial persistence strategies. J Immunol Res. 2019;2019:1-24. doi:10.1155/2019/1356540

44. Alvarez GS, Hélary C, Mebert AM, Wang X, Coradin T, Desimone MF. Antibiotic-loaded silica nanoparticle-collagen composite hydrogels with prolonged antimicrobial activity for wound infection prevention. $J$ Mater Chem B. 2014;2(29):4660. doi: $10.1039 / \mathrm{c} 4 \mathrm{tb} 00327 \mathrm{f}$

45. Shen SC, Ng WK, Shi Z, Chia L, Neoh KG, Tan RBH. Mesoporous silica nanoparticle-functionalized poly(methyl methacrylate)-based bone cement for effective antibiotics delivery. J Mater Sci Mater Med. 2011;22(10):2283-2292. doi:10.1007/s10856-011-4397-1

46. Yan H, Yang H, Li K, Yu J, Huang C. Effects of chlorhexidine-encapsulated mesoporous silica nanoparticles on the anti-biofilm and mechanical properties of glass ionomer cement. Molecules. 2017;22(7):1225. doi:10.3390/ molecules22071225

47. Letchmanan K, Shen SC, Ng WK, et al. Mechanical properties and antibiotic release characteristics of poly(methyl methacrylate)-based bone cement formulated with mesoporous silica nanoparticles. J Mech Behav Biomed Mater. 2017;72: (February):163-170. doi:10.1016/j.jmbbm.2017.05.003

48. Fan W, Li Y, Sun Q, Ma T, Fan B. Calcium-silicate mesoporous nanoparticles loaded with chlorhexidine for both anti- Enterococcus faecalis and mineralization properties. $J$ Nanobiotechnology. 2016;14(1):1-12. doi:10.1186/s12951-016-0224-7

49. Zhou X, Weng W, Chen B, et al. Mesoporous silica nanoparticles/ gelatin porous composite scaffolds with localized and sustained release of vancomycin for treatment of infected bone defects. J Mater Chem B. 2018;6(5):740-752. doi:10.1039/C7TB01246B

50. Chen $\mathrm{X}, \mathrm{Xu} \mathrm{C}, \mathrm{He} \mathrm{H}$. Electrospinning of silica nanoparticles-entrapped nanofibers for sustained gentamicin release. Biochem Biophys Res Commun. 2019;516 (4):1085-1089. doi:10.1016/j.bbrc.2019.06.163

51. Jiménez-Jiménez C, Manzano M, Vallet-Regí M. Nanoparticles coated with cell membranes for biomedical applications. Biology (Basel). 2020;9:406. doi:10.3390/biology9110406

52. Mudakavi RJ, Raichur AM, Chakravortty D. Lipid coated mesoporous silica nanoparticles as an oral delivery system for targeting and treatment of intravacuolar Salmonella infections. RSC Adv. 2014;4(105):61160-61166. doi:10.1039/c4ra12973c

53. Yang S, Han X, Yang Y, et al. Bacteria-targeting nanoparticles with microenvironment-responsive antibiotic release to eliminate intracellular staphylococcus aureus and associated infection. $A C S$ Appl Mater Interfaces. 2018;10(17):14299-14311. doi:10.1021/ acsami.7b15678

54. Chen X, Liu Y, Lin A, et al. Folic acid-modified mesoporous silica nanoparticles with $\mathrm{pH}$-responsiveness loaded with Amp for an enhanced effect against anti-drug-resistant bacteria by overcoming efflux pump systems. Biomater Sci. 2018;6 (7):1923-1935. doi:10.1039/c8bm00262b 
55. Li L, Wang H. Enzyme-coated mesoporous silica nanoparticles as efficient antibacterial agents in vivo. Adv Healthc Mater. 2013;2 (10):1351-1360. doi:10.1002/adhm.201300051

56. Wang Y, Nor YA, Song $\mathrm{H}$, et al. Small-sized and large-pore dendritic mesoporous silica nanoparticles enhance antimicrobial enzyme delivery. J Mater Chem B. 2016;4(15):2646-2653. doi:10.1039/C6TB00053C

57. Song H, Ahmad Nor Y, Yu M, et al. Silica nanopollens enhance adhesion for long-term bacterial inhibition. J Am Chem Soc. 2016;138(20):6455-6462. doi:10.1021/jacs.6b00243

58. Xu C, He Y, Li Z, Ahmad Nor Y, Ye Q. Nanoengineered hollow mesoporous silica nanoparticles for the delivery of antimicrobial proteins into biofilms. J Mater Chem B. 2018;6(13):1899-1902. doi:10.1039/C7TB03201C

59. Durack E, Mallen S, O'Connor PM, et al. Protecting bactofencin A to enable its antimicrobial activity using mesoporous matrices. Int $J$ Pharm. 2019;558(December2018):9-17. doi:10.1016/j. ijpharm.2018.12.035

60. Braun K, Pochert A, Lindén M, et al. Membrane interactions of mesoporous silica nanoparticles as carriers of antimicrobial peptides. $J$ Colloid Interface Sci. 2016;475:161-170. doi:10.1016/j.jcis.2016.05.002

61. Tenland E, Pochert A, Krishnan N, et al. Effective delivery of the anti-mycobacterial peptide NZX in mesoporous silica nanoparticles. PLoS One. 2019;14(2):1-16. doi:10.1371/journal. pone. 0212858

62. Balaure PC, Boarca B, Popescu RC, et al. Bioactive mesoporous silica nanostructures with anti-microbial and anti-biofilm properties. Int $J$ Pharm. 2017;531(1):35-46. doi:10.1016/j. ijpharm.2017.08.062

63. de Azevedo M, Oliveira LF, Teles da Silva LV, et al. Antioxidant and antimicrobial activity of red propolis embedded mesoporous silica nanoparticles. Drug Dev Ind Pharm. 2020;46 (7):1199-1208. doi:10.1080/03639045.2020.1782423

64. Gao F, Zhou H, Shen Z, et al. Synergistic antimicrobial activities of tea tree oil loaded on mesoporous silica encapsulated by polyethyleneimine. J Dispers Sci Technol. 2020;41 (12):1859-1871. doi:10.1080/01932691.2019.1637755

65. Chen $\mathrm{H}$, Shen $\mathrm{Z}$, Wu P, et al. Long effective tea tree oil/mesoporous silica sustained release system decorated by polyethyleneimine with high antibacterial performance. J Dispers Sci Technol. 2020:1-12. doi:10.1080/01932691.2020.1772816.

66. Trewyn BG, Whitman CM, Lin VSY. Morphological control of room-temperature ionic liquid templated mesoporous silica nanoparticles for controlled release of antibacterial agents. Nano Lett. 2004;4(11):2139-2143. doi:10.1021/nl048774r

67. Wang X, Shi L, Zhang J, Cheng J, Wang X. Self-assembly fabrication, microstructures and antibacterial performance of layer-structured montmorillonite nanocomposites with cationic silica nanoparticles. RSC Adv. 2017;7(50):31502-31511. doi:10.1039/c7ra04353h

68. Bai Y-M, Mao J, Xiong LD, et al. Bimodal antibacterial system based on quaternary ammonium silane-coupled core-shell hollow mesoporous silica. Acta Biomater. 2019;85:229-240. doi:10.1016/j.actbio.2018.12.037

69. Velikova N, Mas N, Miguel-Romero L, et al. Broadening the antibacterial spectrum of histidine kinase autophosphorylation inhibitors via the use of $\varepsilon$-poly-L-lysine capped mesoporous silica-based nanoparticles. Nanomed Nanotechnol Biol Med. 2017;13(2):569-581. doi:10.1016/j.nano.2016.09.011

70. Pedraza D, Díez J, Barba II, Colilla M, Vallet-Regi M. Aminefunctionalized mesoporous silica nanoparticles: a new nanoantibiotic for bone infection treatment. Biomed Glas. 2018;4(1):1-12. doi:10.1515/bglass-2018-0001
71. González B, Colilla M, Díez J, et al. Mesoporous silica nanoparticles decorated with polycationic dendrimers for infection treatment. Acta Biomater. 2018;68:261-271. doi:10.1016/j. actbio.2017.12.041

72. Cheng G, Zhang Z, Chen S, Bryers JD, Jiang S. Inhibition of bacterial adhesion and biofilm formation on zwitterionic surfaces. Biomaterials. 2007;28(29):4192-4199. doi:10.1016/j. biomaterials.2007.05.041

73. Izquierdo-Barba I, Sánchez-Salcedo S, Colilla M, et al. Inhibition of bacterial adhesion on biocompatible zwitterionic SBA-15 mesoporous materials. Acta Biomater. 2011;7(7):2977-2985. doi:10.1016/j.actbio.2011.03.005

74. Encinas N, Angulo M, Astorga C, Colilla M, Izquierdo-Barba I, Vallet-Regí M. Mixed-charge pseudo-zwitterionic mesoporous silica nanoparticles with low-fouling and reduced cell uptake properties. Acta Biomater. 2019;84:317-327. doi:10.1016/j. actbio.2018.12.012

75. Knowles BR, Wagner P, Maclaughlin S, Higgins MJ, Molino PJ. Silica nanoparticles functionalized with zwitterionic sulfobetaine siloxane for application as a versatile antifouling coating system. ACS Appl Mater Interfaces. 2017;9(22):18584-18594. doi:10.1021/acsami.7b04840

76. Ji F, Sun H, Qin Z, et al. Engineering polyzwitterion and polydopamine decorated doxorubicin-loaded mesoporous silica nanoparticles as a pH-sensitive drug delivery. Polymers (Basel). 2018;10(3):1-17. doi:10.3390/polym10030326

77. Sanchez-Salcedo S, Vallet-Regí M, Shahin SA, Glackin CA, Zink JI. Mesoporous core-shell silica nanoparticles with anti-fouling properties for ovarian cancer therapy. Chem Eng J. 2018;340:114-124. doi:10.1016/j.cej.2017.12.116

78. Mirzajani F, Ghassempour A, Aliahmadi A, Esmaeili MA. Antibacterial effect of silver nanoparticles on Staphylococcus aureus. Res Microbiol. 2011;162(5):542-549. doi:10.1016/j. resmic.2011.04.009

79. Lee W, Kim K-J, Lee DG. A novel mechanism for the antibacterial effect of silver nanoparticles on Escherichia coli. BioMetals. 2014;27(6):1191-1201. doi:10.1007/s10534-014-9782-z

80. Salomoni R, Léo P, Montemor A, Rinaldi B, Rodrigues M. Antibacterial effect of silver nanoparticles in Pseudomonas aeruginosa. Nanotechnol Sci Appl. 2017;10:115-121. doi:10.2147/NSA.S133415

81. Liao C, Li Y, Bactericidal TS. Cytotoxic properties of silver nanoparticles. Int J Mol Sci. 2019;20(2):449. doi:10.3390/ ijms20020449

82. Yin IX, Zhang J, Zhao IS, Mei ML, Li Q, Chu CH. The antibacterial mechanism of silver nanoparticles and its application in dentistry. Int J Nanomedicine. 2020;15:2555-2562. doi:10.2147/IJN.S246764

83. Pugazhendhi A, Prabakar D, Jacob JM, Karuppusamy I, Saratale RG. Synthesis and characterization of silver nanoparticles using Gelidium amansii and its antimicrobial property against various pathogenic bacteria. Microb Pathog. 2018;114:41-45. doi:10.1016/j.micpath.2017.11.013

84. Liong M, France B, Bradley KA, Zink JI. Antimicrobial activity of silver nanocrystals encapsulated in mesoporous silica nanoparticles. Adv Mater. 2009;21(17):1684-1689. doi:10.1002/ adma.200802646

85. Tian Y, Qi J, Zhang W, Cai Q, Jiang X. Facile, one-pot synthesis, and antibacterial activity of mesoporous silica nanoparticles decorated with well-dispersed silver nanoparticles. ACS Appl Mater Interfaces. 2014;6(15):12038-12045. doi:10.1021/am5026424

86. Wan X, Zhuang L, She B, Deng Y, Chen D, Tang J. In-situ reduction of monodisperse nanosilver on hierarchical wrinkled mesoporous silica with radial pore channels and its antibacterial performance. Mater Sci Eng C. 2016;65:323-330. doi:10.1016/j. msec.2016.04.058 
87. Song Y, Jiang H, Wang B, Kong Y, Chen J. Silver-incorporated mussel-inspired polydopamine coatings on mesoporous silica as an efficient nanocatalyst and antimicrobial agent. ACS Appl Mater Interfaces. 2018;10(2):1792-1801. doi:10.1021/acsami.7b18136

88. Montalvo-Quirós S, Gómez-Graña S, Vallet-Regí M, PradosRosales RC, González B, Luque-Garcia JL. Mesoporous silica nanoparticles containing silver as novel antimycobacterial agents against Mycobacterium tuberculosis. Colloids Surf B Biointerfaces. 2021;197:111405. doi:10.1016/j.colsurfb.2020.111405

89. Ambrogi V, Pietrella D, Donnadio A, et al. Biocompatible alginate silica supported silver nanoparticles composite films for wound dressing with antibiofilm activity. Mater Sci Eng C. 2020;112:110863. doi:10.1016/j.msec.2020.110863

90. Dizaj SM, Lotfipour F, Barzegar-Jalali M, Zarrintan MH, Adibkia K. Antimicrobial activity of the metals and metal oxide nanoparticles. Mater Sci Eng C. 2014;44:278-284. doi:10.1016/j. msec.2014.08.031

91. Parham S, Wicaksono DHB, Bagherbaigi S, Lee SL, Nur H. Antimicrobial treatment of different metal oxide nanoparticles: a critical review. J Chinese Chem Soc. 2016;63(4):385-393. doi:10.1002/jccs. 201500446

92. Abo-zeid Y, Williams GR. The potential anti-infective applications of metal oxide nanoparticles: a systematic review. Wiley Interdiscip Rev Nanomed Nanobiotechnol. 2020;12(2):1-36. doi:10.1002/wnan. 1592

93. Hachemaoui M, Boukoussa B, Mokhtar A, et al. Dyes adsorption, antifungal and antibacterial properties of metal loaded mesoporous silica: effect of metal and calcination treatment. Mater Chem Phys. 2020;256:123704. doi:10.1016/j. matchemphys.2020.123704

94. Leng D, Li Y, Zhu J, et al. The Antibiofilm Activity and Mechanism of Nanosilver- and Nanozinc-Incorporated Mesoporous Calcium-Silicate Nanoparticles. Int J Nanomedicine. 2020;15:3921-3936. doi:10.2147/IJN.S244686

95. Dinali R, Ebrahiminezhad A, Manley-Harris M, Ghasemi Y, Berenjian A. Iron oxide nanoparticles in modern microbiology and biotechnology. Crit Rev Microbiol. 2017;43(4):493-507. doi:10.1080/1040841X.2016.1267708

96. Saqib S, Munis MFH, Zaman W, et al. Synthesis, characterization and use of iron oxide nano particles for antibacterial activity. Microsc Res Tech. 2019;82(4):415-420. doi:10.1002/jemt.23182

97. Xu JW, Yao K, Xu ZK. Nanomaterials with a photothermal effect for antibacterial activities: an overview. Nanoscale. 2019;11 (18):8680-8691. doi:10.1039/c9nr01833f

98. Arias LS, Pessan JP, Vieira APM, Tmt DL, Delbem ACB, Monteiro DR. Iron oxide nanoparticles for biomedical applications: a perspective on synthesis, drugs, antimicrobial activity, and toxicity. Antibiotics. 2018;7:2. doi:10.3390/antibiotics7020046

99. Mebert AM, Aimé C, Alvarez GS, et al. Silica core-shell particles for the dual delivery of gentamicin and rifamycin antibiotics. $J$ Mater Chem B. 2016;4(18):3135-3144. doi:10.1039/ c6tb00281a
100. Gounani Z, Asadollahi MA, Pedersen JN, et al. Mesoporous silica nanoparticles carrying multiple antibiotics provide enhanced synergistic effect and improved biocompatibility. Colloids Surf B Biointerfaces. 2019;175:498-508. doi:10.1016/j. colsurfb.2018.12.035

101. Kuthati Y, Kankala RK, Lin SX, Weng CF, Lee CH. pHTriggered Controllable Release of Silver-Indole-3 acetic acid complexes from Mesoporous Silica Nanoparticles (IBN-4) for effectively killing malignant bacteria. Mol Pharm. 2015;12 (7):2289-2304. doi:10.1021/mp500836w

102. Greco O, Folkes LK, Wardman P, Tozer GM, Dachs GU. Development of a novel enzyme/prodrug combination for gene therapy of cancer: horseradish peroxidase/indole-3-acetic acid. Cancer Gene Ther. 2000;7(11):1414-1420. doi:10.1038/sj.cgt.7700258

103. Yu Q, Deng T, Lin FC, Zhang B, Zink JI. Supramolecular assemblies of heterogeneous mesoporous silica nanoparticles to co-deliver antimicrobial peptides and antibiotics for synergistic eradication of pathogenic biofilms. ACS Nano. 2020;14 (5):5926-5937. doi:10.1021/acsnano.0c01336

104. Cheng Y, Zhang Y, Deng W, Hu J. Antibacterial and anticancer activities of asymmetric lollipop-like mesoporous silica nanoparticles loaded with curcumin and gentamicin sulfate. Colloids Surf B Biointerfaces. 2020;186:110744. doi:10.1016/j. colsurfb.2019.110744

105. Wang Y, Ding X, Chen Y, et al. Antibiotic-loaded, silver core-embedded mesoporous silica nanovehicles as a synergistic antibacterial agent for the treatment of drug-resistant infections. Biomaterials. 2016;101:207-216. doi:10.1016/j.biomaterials.2016.06.004

106. Chang Z-M, Wang Z, MengLu M, et al. Janus silver mesoporous silica nanobullets with synergistic antibacterial functions. Colloids Surf B Biointerfaces. 2017;157:199-206. doi:10.1016/j. colsurfb.2017.05.079

107. Tasia W, Lei C, Cao Y, Ye Q, He Y, Xu C. Enhanced eradication of bacterial biofilms with DNase I-loaded silver-doped mesoporous silica nanoparticles. Nanoscale. 2020;12(4):2328-2332. doi:10.1039/c9nr08467c

108. Song Y, Cai L, Tian Z, Wu Y, Phytochemical CurcuminCoformulated CJ. Silver-decorated melanin-like polydopamine/ mesoporous silica composites with improved antibacterial and chemotherapeutic effects against drug-resistant cancer cells. ACS Omega. 2020;5(25):15083-15094. doi:10.1021/ acsomega.0c00912

109. Martínez-Carmona M, Izquierdo-Barba I, Colilla M, Vallet-Regí M. Concanavalin A-targeted mesoporous silica nanoparticles for infection treatment. Acta Biomater. 2019;96:547-556. doi:10.1016/j.actbio.2019.07.001

110. Michailidis M, Sorzabal-Bellido I, Adamidou EA, et al. Modified mesoporous silica nanoparticles with a dual synergetic antibacterial effect. ACS Appl Mater Interfaces. 2017;9(44):38364-38372. doi:10.1021/acsami.7b14642

\section{Publish your work in this journal}

The International Journal of Nanomedicine is an international, peerreviewed journal focusing on the application of nanotechnology in diagnostics, therapeutics, and drug delivery systems throughout the biomedical field. This journal is indexed on PubMed Central, MedLine, CAS, SciSearch ${ }^{\mathbb{R}}$, Current Contents ${ }^{\mathbb{R}} /$ Clinical Medicine, $^{2}$
Journal Citation Reports/Science Edition, EMBase, Scopus and the Elsevier Bibliographic databases. The manuscript management system is completely online and includes a very quick and fair peer-review system, which is all easy to use. Visit http://www.dovepress.com/ testimonials.php to read real quotes from published authors. 